\title{
Efficacy of Antimicrobials Against Unstressed or Cold-Stress Adapted Salmonella Cells and Surrogate Enterococcus faecium on both Broiler Carcasses and Wings
}

\author{
Lacey Lemonakis
}

Follow this and additional works at: https://researchrepository.wvu.edu/etd

\author{
Recommended Citation \\ Lemonakis, Lacey, "Efficacy of Antimicrobials Against Unstressed or Cold-Stress Adapted Salmonella \\ Cells and Surrogate Enterococcus faecium on both Broiler Carcasses and Wings" (2017). Graduate \\ Theses, Dissertations, and Problem Reports. 6058. \\ https://researchrepository.wvu.edu/etd/6058
}

This Thesis is protected by copyright and/or related rights. It has been brought to you by the The Research Repository @ WVU with permission from the rights-holder(s). You are free to use this Thesis in any way that is permitted by the copyright and related rights legislation that applies to your use. For other uses you must obtain permission from the rights-holder(s) directly, unless additional rights are indicated by a Creative Commons license in the record and/ or on the work itself. This Thesis has been accepted for inclusion in WVU Graduate Theses, Dissertations, and Problem Reports collection by an authorized administrator of The Research Repository @ WVU. For more information, please contact researchrepository@mail.wvu.edu. 
Efficacy of Antimicrobials Against Unstressed or Cold-Stress Adapted Salmonella Cells and Surrogate Enterococcus faecium on both Broiler Carcasses and Wings

\section{Lacey Lemonakis}

Thesis submitted to the Davis College of Agriculture, Forestry and Consumer Sciences at West Virginia University in partial fulfillment of the requirements for the Degree of Master of Science in Nutrition and Food Science

Cangliang Shen, PhD., Chair

Brett P. Kenney, PhD.

Kristen Matak, PhD.

Division of Animal and Nutritional Sciences

West Virginia University

Morgantown, West Virginia

2017

Key words: broiler, antimicrobials, Salmonella, Enterococcus, cold-stress Copyright 2017 Lacey Lemonakis 


\section{Abstract \\ Efficacy of Antimicrobials Against Unstressed or Cold-Stress Adapted Salmonella Cells and Surrogate Enterococcus faecium on both Broiler Carcasses and Wings Lacey Lemonakis}

The aim of this study was to evaluate the microbial quality of broiler carcasses and efficacy of antimicrobials on unstressed or cold-stress adapted cells of Salmonella and Enterococcus on broiler carcasses and wings. Broiler carcasses and wings were processed at a small USDAinspected slaughter facility, located in West Virginia. The first part of the study included 42 broiler carcasses that had been pre-enriched in Buffered Peptone Water then secondarily-enriched into Rappaport Vassiliadis following incubation. Secondary enrichment broth was then streaked on to Xylose Lysine Tergitol 4 (XLT-4) and HardyCHROM ${ }^{\mathrm{TM}}$ agar for Salmonella detection; and further confirmation was performed using an API 20E kit and Latex Agglutination test. Various petrifilms such as aerobic plate count (APC), Escherichia coli (ECC), total coliforms (TCC), and yeast/ mold were analyzed. APC, ECC/TCC and Yeast/ Mold counts were 2.61, 1.08, and $2.37 \log _{10} \mathrm{CFU} / \mathrm{mL}$ respectively on broiler carcasses. Thirty and forty percent of the carcasses were positive for detection of Salmonella spp. and Escherichia coli (0.48 to $\left.1.70 \log _{10} \mathrm{CFU} / \mathrm{mL}\right)$ respectively. Study II included fresh broiler carcasses and wings; these meat products were inoculated with unstressed and cold-stress adapted (grown in $4^{\circ} \mathrm{C}$ for 7 days) Salmonella Typhimurium ATCC 14028, Salmonella Tennessee ATCC 10722, and Enterococcus faecium ATCC8459 (roughly 5.5 to 6.5 $\log _{10} \mathrm{CFU} / \mathrm{mL}$ ). Carcasses and wings were later assigned to undipped (control) or dipped treatments, these treatments consisted of peroxyacetic acid (PAA; 0.1\%), lactic acid (LA; 5\%), lactic/ citric acid blend (LCA; 2.5\%), and sodium hypochlorite (SH; 67-69 ppm). Dip treatments were 30 seconds with carcasses and wings, with wings having a 2 minute drying period following 
dipping. Immediately following treatments, surviving bacteria were recovered onto selective and non-selective agar to analyze total Salmonella and Enterococcus. Carcasses had antimicrobials reduce cold-stress adapted cells (1.1 to 1.7 and 1.0 to $\left.2.1 \log _{10} \mathrm{CFU} / \mathrm{mL}\right)$ more $(P<0.05)$ than the unstressed cells ( 0.7 to 1.5 and 0.2 to $1.7 \log _{10} \mathrm{CFU} / \mathrm{mL}$ ) for Salmonella and Enterococcus. As for wings, cold-stress adapted Salmonella cells were more sensitive $(P>0.05)$ to antimicrobials (reduced by 0.9 to $1.5 \log _{10} \mathrm{CFFU} / \mathrm{mL}$ ) than the unstressed cells (reduced by 0.5 to $1.2 \log _{10}$ $\mathrm{CFU} / \mathrm{mL})$. However, unstressed and cold-stress adapted Enterococcus behaved similar, $(P>0.05)$, with reductions ranging from 0.9 to $2.0 \log _{10} \mathrm{CFU} / \mathrm{mL}$. Salmonella and Enterococcus reductions on carcasses and wings increased in the following order: $\mathrm{SH} \leq \mathrm{LCA}<\mathrm{LA}<\mathrm{PAA}$, irrespective of unstressed or cold-stress adapted cells. Application of post-chilling, antimicrobial treatment could be a beneficial intervention to Salmonella on locally processed broiler carcasses and wings. With the results of the study, Enterococcus faecium could potentially be used as a surrogate for Salmonella when being used in in-plant validation studies. 


\section{Acknowledgments}

This research project and thesis would not have been possible without the support and inspiration of many people in my life. I would like to extend my sincere gratitude to Dr. Cangliang Shen for his knowledge, guidance, and encouragement to help me grow into the student and the researcher that I am today. I could not have asked for a better mentor. I would like to express my appreciation towards the rest of my graduate committee, Dr. P. Brett Kenney, and Dr. Kristen Matak, for their guidance and instruction throughout my last two years. I would like to give thanks to the many undergraduate students who helped assist me during my time in the research lab: Jordan Garry, Peyton Southhall, Alleda Rose, and Caroline Flynn. My deepest gratitude goes towards my mother, Linda Lyons, and Kris Small for their constant love and support throughout my graduate studies. 


\section{Table of Contents}

$\begin{array}{lll}\text { Abstract } & \text { i }\end{array}$

$\begin{array}{ll}\text { Acknowledgements } & \text { iii }\end{array}$

Table of Contents $\quad$ iv

List of Tables $\quad$ vi

List of Figures $\quad$ vii

1.0 Literature Review 1

1.1 Impact on Food Safety and Consumers 1

1.2 Salmonella spp $\quad 2$

1.3 Evidence of Salmonella in Poultry Products 2

1.4 Introduction to Poultry Processing and Approaches to Pathogen

Control during Processing 5

$\begin{array}{ll}1.5 \text { Enterococcus spp. } & 7\end{array}$

1.6 Bacterial Pathogens used as Surrogates and Significance in Food Safety 9

1.7 Antimicrobial Intervention Approach for Processing 12

$\begin{array}{ll}1.8 \text { Conclusions } & 15\end{array}$

$\begin{array}{ll}2.0 \text { Study Objectives } & 16\end{array}$

$\begin{array}{ll}3.0 \text { Introduction } & 17\end{array}$

$\begin{array}{ll}\text { 4.0 Materials and Methods } & 20\end{array}$ 
4.2 Salmonella and Enterococcus Inoculum Preparation

4.3 Broiler Carcasses and Wings Collection and Inoculation

4.5 Microbial Analysis

4.6 Data Analysis

5.2 Efficacy of Antimicrobials to Inactivate Aerobic Plate Counts and Salmonella 26 


\section{List of Tables}

Table 1. Mean, standard deviation, and range of microbial populations of aerobic plate count (APC), total coliform (TCC), Escherichia coli, and yeast/molds on broiler carcasses. $\quad 40$

Table 2. Aerobic plate counts (APC) recovered from unstressed or cold-stressed Salmonella cells on both broiler carcasses and wings.

Table 3. Unstressed or cold-stressed adapted Salmonella recovered on XLT-4 and HardyCHROM ${ }^{\mathrm{TM}}$ agar from inoculated broiler carcasses.

Table 4. Unstressed or cold-stressed adapted Salmonella recovered on XLT-4 and HardyCHROM ${ }^{\mathrm{TM}}$ agar from inoculated broiler wings.

Table 5. Unstressed or cold-stressed adapted Enterococcus faecium recovered from inoculated both broiler carcasses and wings.

Table 6. Comparing reduction of unstressed or cold-stress adapted Salmonella and Enterococcus faecium recovered from inoculated broiler carcasses.

Table 7. Comparing reduction of unstressed or cold-stress adapted Salmonella and Enterococcus faecium recovered from inoculated broiler wings. 


\section{List of Figures}

Figure 1. List of Serotypes in 2010 Found in Broilers 5

Figure 2. Diagram of the steps involved in poultry processing. $\quad 8$ 


\subsection{Literature Review}

\subsection{Impact on Food Safety and Consumers}

Food-borne illnesses are increasing, creating a serious public health concern. Transmission of food-borne pathogens through the food chain is still an unresolved issue (Galvez et al., 2010). One of the major concerns focuses on the production and distribution of food from the farm to reaching the consumers household to ensure they are receiving wholesome products. Consumers have the right to receive wholesome products, so implementing any interventions to help reduce the risk of cross-contamination in food processing should be influenced. Potentially consumers acquire a food-borne illness when food is improperly handled or cross-contamination occurs. Symptoms most commonly affiliated with food-borne illnesses include cramping, diarrhea and vomiting. Of the many known food-borne pathogens, a select few continuously contaminate our everyday food supply, more specifically ready-to-cook poultry products. The quality and safety of poultry products are affected by the several steps throughout processing and production. As noted, Salmonella spp. are commonly associated with ready-to-eat poultry products (Schraff, 2011). Approximately 1.4 million people are reported with Salmonella in the United States annually (Schraff, 2011). In 2011 the CDC reported an estimated 11\% of food-borne illnesses were affiliated with Salmonella. Schraff, (2011) estimated health related cost to food-borne illness was $\$ 51$ billion; whereas, $\$ 4.43$ million was related to Salmonella.

Industries are advancing technology to a food-borne disease outbreaks. Even with advances in food safety, there are still ongoing challenges. Implementing a more rigorous food safety program and endorsing studies to ensure products are safe for handling and consumption are approaches to eliminate these problems (Bianchini et al., 2014). With the USDA implementing a stricter pathogen reduction standard, it's important for poultry processors to apply new 
interventions to control pathogens such as Salmonella. Food industry is routinely using ingredients that may pose a high risk for Salmonella contamination; this practice is a major concern for food safety programs (Bianchini et al., 2014). Despite the industry's efforts to take preventative measures, recalls and outbreaks continue to occur.

\subsection{Salmonella spp.}

Salmonella are a Gram negative, non-spore forming bacilli in the Enterobacteriaceae family (Jay et al., 2012; Fraser, 2017). Approximately 2,000 serotypes exist and are known to cause human disease (Jay et al., 2012). Optimal growth temperature of Salmonella ranges from $35-37^{\circ} \mathrm{C}$, or body temperature (Fraser, 2017). As for optimal pH, growth is near neutral but a $\mathrm{pH}$ above 9.0 or below 4.0 could be detrimental to the cells (Jay et al., 2012).

Samples are obtained then cultured onto a selective media for Salmonella. Currently, laboratories use many variations of media for isolation of Salmonella. Xylose lysine tergitol 4 (XLT4) tends to be used widely for the isolation of non-typhi Salmonella spp. (XLT-4 AGAR, 1996-2016). For positive detection, colonies will appear black or yellow to red with black centers (XLT-4 AGAR, 1996-2016). This is caused by the production of hydrogen sulfide after incubation for 18- 24 hours (XLT-4 AGAR, 1996-2016). Further examination, morphology, color determination, and further testing for identification and differentiation of species are used (XLT4 AGAR, 1996-2016). A more common testing panel is the API20E kit (XLT-4 AGAR, 19962016). The indicated kit provides conformation to identify which species of Salmonella is present.

\subsection{Evidence of Salmonella in Poultry Products}

Chickens are a natural host for pathogenic bacteria. Salmonella occur naturally in the intestinal tracts of broilers (Tamblyn and Conner, 1997). Poultry are asymptomatic carries of most 
serotypes of Salmonella (McKee, 2012). Centers for Disease Control and Prevention (2014) reported that processed chicken products have been associated with numerous Salmonella outbreaks. Bacteria-related food safety concerns relate back to poultry meat that has not been properly cooked or to cross-contamination. These scenarios lead to foodborne disease outbreaks. Illnesses can arise from the moments broiler processed starts to the moment consumers receive their poultry products.

Salmonella contributes to $35.1 \%$ of illnesses related to poultry products (Batz et al., 2011). Among the thousands of serotypes of Salmonella spp., the top 3, causing food borne illness, are Enteritidis (19\%), Typhimurium (14\%), and Newport (10\%) (Bourassa et al., 2015). Figure 1 presents the most common identified serotypes among meat and poultry classes. The Centers for Disease Control (2011) reported that Salmonella is responsible for $11 \%$ of food-borne illnesses; $35 \%$ of these require hospitalization and $28 \%$ result in death. Outside of illnesses related to food, cases can also arise from the laboratory setting. From 2010 to 2014, at least 158 cases of laboratory-associated infections with Salmonella Typhimurium ATCC 14028 were reported by PulseNet USA (Hu and Gurtler, 2017).

Within industries, there are methods applied to help provide safe food and steps to prevent cross contamination. One of the biggest concerns is reducing bacteria in the poultry products itself. Regulations and safety standards are presented by the USDA-Food Safety and Inspection Services (FSIS). USDA-FSIS requires a Hazard Analysis and Critical Control Point (HACCP) plan that must be implemented in food processing plants (Russell, 2005). HACCP is a proactive written plan for maintaining the control of potentially hazardous food at the critical point of food processing and preparation (Compliance Guideline, 2010). Certain criteria requirements are set and processing facilities are required to comply with these performance standards. That includes 
successful conduct and monitoring the critical control points. Performance standards require routine testing for presence of Salmonella in the processing plants. New performance standards allow a certain percentage of positive bacteria present in a sampling period. A presence of positive samples for Salmonella must remain below an overall of 7.5\% (McKee, 2012).

The food industry has been in continuous search of quick and cost-effective methods to help enumerate and identify microorganisms on food products and the equipment used to process food products (Russell, 2005). Since there is high positive rates of Salmonella, the poultry industry has set up standard post-harvest procedures for processors to follow. The major area of focus is processing which can be steps including de-feathering and evisceration. In further research, processing plants need to be closely monitored as to why evisceration is the leading factor in producing such high positive values of these two pathogen. This leads to the question of what steps can be implemented to reduce the high values. 


\begin{tabular}{|l|c|c|c|}
\hline \multicolumn{1}{|c|}{ Serotypes 2010 } & $\begin{array}{c}\text { Number of } \\
\text { Isolates }\end{array}$ & $\begin{array}{c}\text { Percent of Total } \\
\text { Positive }\end{array}$ & $\begin{array}{c}\text { Percent of } \\
\text { Analyzed } \\
\text { Samples }\end{array}$ \\
\hline Kentucky & 208 & 45.41 & 3.05 \\
\hline Enteritidis & 124 & 27.07 & 1.82 \\
\hline Typhimurium 5- & 27 & 5.90 & 0.40 \\
\hline Heidelberg & 16 & 3.49 & 0.23 \\
\hline 'Typhimurium & 14 & 3.06 & 0.21 \\
\hline '4.5.12:i:- & 10 & 2.18 & 0.15 \\
\hline Johannesburg & 6 & 1.31 & 0.09 \\
\hline Schwarzengrund & 5 & 1.09 & 0.07 \\
\hline Senftenber & 5 & 1.09 & 0.07 \\
\hline Berta & 4 & 0.87 & 0.06 \\
\hline Braenderup & 4 & 0.87 & 0.06 \\
\hline Thompson & 4 & 0.87 & 0.06 \\
\hline Other serotypes & 24 & 5.24 & 0.35 \\
\hline Unidentified & 5 & 1.09 & 0.07 \\
\hline Total serotyped isolates & 456 & & 6.68 \\
\hline Not typed & 2 & & 0.03 \\
\hline Total positve & 458 & & 6.71 \\
\hline
\end{tabular}

Figure 1. Profile of Serotypes Analyzed from PR/HACCP Verification Samples by Calendar Year. Broilers (1998-2005 'A' Set Samples; 2006-2010 All Samples) (*The percentages listed for due to rounding. a. The ten most comm sum of the data in the Percent of Analyzed Samples column by name while less commonly identified When there is more than one serotype serotypes are included in the -other serotypesl category. - unidentifiedl designation includes in tenth place, all serotypes in tenth place are listed. $\mathbf{b}$. The determined including those that wer serotype could not be isolates fitting the designation in blely named through antigenic formulas. c Prior to 2004, Typhimurium includes Typhimurium 5-re included in the -unidentified isolatesl category. $d$ most commonly identified serotypes (Serotypes Profile of Salmonella December 2010)

\subsection{Introduction to poultry processing and approaches to pathogen control during processing}

The safety and quality of poultry products is affected by the various steps throughout production. In the year 2006, the USDA-FSIS began a new initiative to reduce the levels of Salmonella in meat and poultry products (U.S. Department of Agriculture, Food Safety and 
Inspection Service, 2006). Salmonella commonly occur in live poultry, plus contaminate the meat itself during the slaughtering area (McKee, 2012). Once the broilers are transferred out of the slaughter stages to other areas the broilers may carry bacteria and contaminate other equipment (Mckee, 2012). A study by the USDA-FSIS reported that roughly $4 \%$ of broilers that enter the processing plant tested positive for Salmonella, but that number increases to $35 \%$ when leaving the processing facility (Lillard, 1989).

At processing plants, broilers undergo several processing steps before the final poultry product is complete. Those steps include stunning, exsanguination, scalding, picking, evisceration, and carcass chilling before packaging (Figured 2). The major concern during the processing is evisceration. During this procedure, edible and inedible viscera are removed from the carcass. The body cavity of the broiler is opened and the inside viscera are harvested. Thus can lead to crosscontamination from intestinal microorganisms spreading to other parts of the carcasses. In the removal of the internal organs, processors must take caution in removing the intestines and digestive tract. Salmonella are known to harbor and grow within these two areas of the broilers. If the gut is torn during the evisceration process, microbial contamination will occur, and will lead to cross-contamination of other broiler carcasses (Fanatico, 2003). After evisceration is complete carcasses are placed in a chiller tank. Before being placed in the chiller tank, carcasses must go through an inspection to determine if there is any fecal contamination. Any present fecal matter on the broilers must be sprayed with water or an antimicrobial mix to remove the matter.

In the processing industry many methods are used for reducing or eliminating bacteria on the birds. Facilities use a spraying mix of water and antimicrobial on-line reprocessing (OLR) or another method of inside-outside bird washer (IOBW). These two methods are generally used after an inspection of the carcass takes place. With this technique, approximately $1 \log$ CFU/unit 
bacterial reduction can be attained, although the results may not be consistent due to many factors, such as the amount of the carcass that is being covered with the spray mix or the pressure of the sprayer. Brashears et al., (2001) reported that high pressure sprayers might be unfavorable by forcing bacteria into the skin of the carcasses.

As for another technique, there are two approved methods used for chilling carcasses, including immersion ice water chilling and air chilling, which are widely used in the U.S. and European Union. Immersion is when the carcass are dipped in a tank that contains water chilled below $40^{\circ} \mathrm{F}$ (Compliance Guideline 2010). On the other hand, air chilling mists carcasses with water in a tight air chilled environment (Compliance Guideline, 2010). Most of the poultry processing plants in the United States use immersion chilling since it is more efficient. Immersion chilling consist of multiple tanks. There is a pre-chiller and a post-chiller tank. Pre-chiller is a term used when reducing the temperature of the carcasses after processing; whereas, a post-chilling tank is used as a dip treatment with antimicrobials to help decrease microbial loads (Compliance Guideline, 2010). These mixes used in post-dipping treatments contain organic acids or chlorinated products. Although facilities use different variations of antimicrobial washes, different interventions may or may not be applicable for use, meaning that specific amounts are allowed versus duration of contact time. Could the chilling process be the most effective approach to help inactivate foodborne pathogens, taking into consideration exposure time of the pathogens to the antimicrobial treatments? 


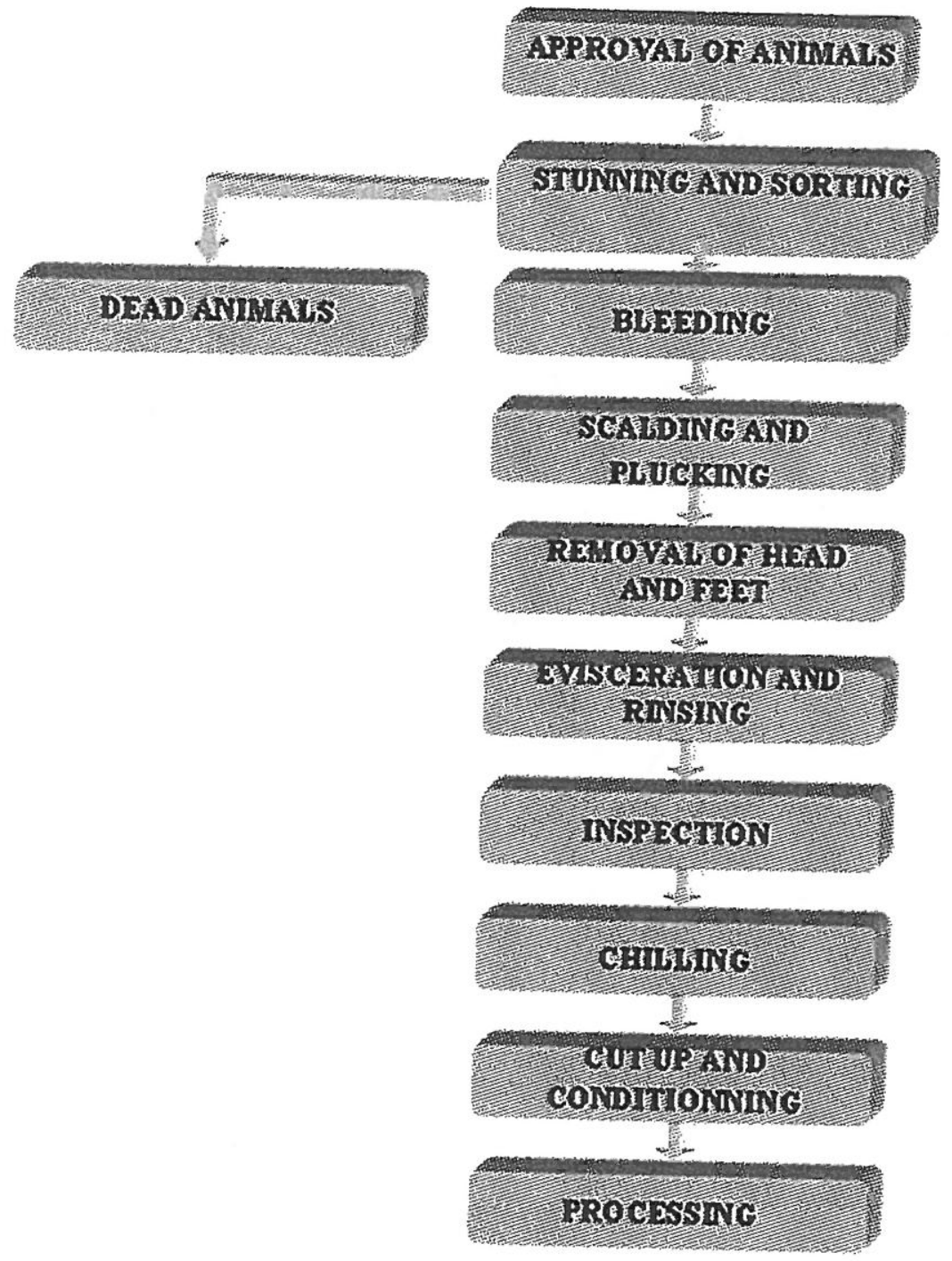

Figure 2. Poultry slaughtering and processing: main steps. (2. Sectoral Economic and Energy Profiles, 2015)

\subsection{Enterococcus spp.}

Enterococcus genus belong to a group of microorganisms known as lactic acid bacteria (LAB) (Moreno et al., 2006). Bacteria of the genus Enterococcus or enterococci, includes more than 30 species (formerly the "faecal" or Lancefield group D streptococci) (Giraffa, 2002; Jay et al., 2005)). They are ubiquitous microorganisms, but have a predominant habitat in the 
gastrointestinal tract of humans and animals (Giraffa, 2002). This potential foodborne bacterium is classified as a Gram positive, non-spore forming and facultative anaerobic cocci cells that occur singly, in pairs or in short chains, (Jay et al., 20012; Moreno et al., 2006; Bianchini et al., 2014). Enterococcus can grow in the presence or $6.5 \% \mathrm{NaCl}$, at a $\mathrm{pH}$ of 9.6 and the can survive heating at $60^{\circ} \mathrm{C}$ for 30 minutes (Moreno et al., 2006). A select amount of species in this genus can grow in temperatures from 10 to $45{ }^{\circ} \mathrm{C}$ (Moreno et al., 2006). Various selection of media are recommended for culturing this bacteria, which include TSA agar and blood agar 5\% (Enterococcus, Hardy Diagnostics, 1996-2016). Whereas for selective isolation, Bile Esculin Azide (BEA) and Mannitol Salt agar (Enterococcus, Hardy Diagnostics, 1996-2016). Growth during incubation last 18-24 hours (Enterococcus, Hardy Diagnostics, 1996-2016). Once grown on media, positive Enterococcus spp. appear to have a smooth, cream or white colonies (Enterococcus, Hardy Diagnostics, 1996-2016). After colonies appear positive on the media, further biochemical test can be conducted for confirmation. Those test consist of catalasenegative, PYR-positive and LAP-positive (Enterococcus, Hardy Diagnostics, 1996-2016).

\subsection{Bacterial Pathogens used as Surrogates and Significance in Food Safety}

U.S. Food and Drug Administration (U.S. Food and Drug Administration, Center for Food Safety and Applied Nutrition, 2001) define a surrogate as "a non-pathogenic species and strain responding to a particular treatment in a manner equivalent to a pathogenic species and strain." Indicator and surrogate microorganisms are used for a variety of uses and purposes in the food systems (Busta et al., 2003). This includes evaluating quality or the safety of processed or raw foods and validating the effectiveness of microbial control measures (Busta et al., 2003). In terms of evaluating the efficacy of given processing treatments in food systems, surrogate microorganisms are more commonly used in place of foodborne pathogens in challenge tests, 
either done in a laboratory setting or in food manufacturing plants (Hu and Gurtler, 2017). Surrogate microorganisms with both characteristics and behaviors similar to a pathogen being evaluated can be extremely useful in decontamination steps throughout processing (Bianchini et al., 2014). The use of surrogates are a nonpathogenic microorganism with specific selected strains prepared in either a laboratory and inoculated into food products or organisms that can be naturally occurring (U.S. Food and Drug Administration, Center for Food Safety and Applied Nutrition, 2001). A practical limitation of process validation, is that the actual pathogens can't be taken in to a food processing facility (Niebuhr et al., 2008). Foodborne pathogens must be handled in a level 2 biosafety facility with personnel who are appropriately trained for the scenario ( $\mathrm{Hu}$ and Gurtler, 2017). The use of target pathogens in challenge studies can be ideal, but can be devastating if improperly handled. Mishandling of a pathogen can affect the researcher's safety, food safety, and even the safety of the processing environment ( $\mathrm{Hu}$ and Gurtler, 2017).

Surrogates are generally selected from a population of well-known organisms that also have well-defined characteristics and a long history of avirulence which can easily be differentiated from other microflora (Kim and Harrison, 2009). When the laboratory is selecting a surrogate a review of the history of that specific surrogate is important when using it as a representation of the pathogenic microorganism (Greenberg et al., 2010). When choosing a surrogate for food intervention studies, the surrogate must justify support and documentation with regards to the target pathogen, food and intervention treatment being evaluated ( $\mathrm{Hu}$ and Gurtler, 2017). The selection of appropriate surrogates is important in regards to specific interventions or the food process that is being imitated (Hu and Gurtler, 2017). Although it may not always be possible to use a surrogate that correlates with the pathogen being targeted in certain situations. 
As previously noted, surrogates are used to replace pathogenic bacteria used in a challenge test. When looking at past studies, appropriate measures are used when selecting a surrogate in today research. Although a researcher must carefully select specific strains of surrogate bacteria to provide a proper margin of safety but also must be careful in not selecting a surrogate that is over resistant (Friedly et al., 2008). Enterococcus faecium has been used as a surrogate in a number of studies pertaining to thermal lethality (Bianchini et al., 2014). In a study by Jeong et al., (2011), Enterococcus faecium was used as a surrogate for Salmonella spp. in validating dry heat process in almonds. This microorganism, Enterococcus faecium, is generally selected due to its nature and similarities with Salmonella spp., which are commonly found in poultry products. Enterococcus faecium is widely used in food due to its high thermal resistance (Hardie and Whiley, 1997; Morrison et al., 1997). Enterococcus faecium has the ability to grow in a wide range of temperatures (Murray 1990; Devriese et al., 1993) with a presence of salt and in lower pH values (San Perez et al., 1982; Giraffa et al., 1997). Channaiah et al., (2016) used Enterococcus faecium in a study and demonstrated greater thermal resistance compared with Salmonella during bun baking and could serve as a conservative surrogate to validate thermal process lethality in commercial bun baking operations. In a study conducted by Enache et al., (2015), it was reported that $E$. faecium is a conservative but appropriate surrogate for Salmonella under testing conditions. A study conducted by Niebuhr et al., (2008), concluded from their study that bacteria, either individually or collectively, have the potential to be used to validate meat processes for the reduction of Salmonella. Use of surrogates in future studies will be beneficial to not only researchers but to industries as well. 


\subsection{Antimicrobial Intervention Approaches for Processing}

Poultry processing facilities are trying to control or even improve the safety of food products by decontaminating the carcasses or products during or at the end of production (Bolder, 1997). Laury et al. (2009) reported that antimicrobials are commonly used in the industry to reduce pathogen loads. Bolder (1997) specified that antimicrobial interventions are applied to poultry products to both physically and chemically reduce numbers of pathogens such as Salmonella spp. in U.S. processing plants and to prevent human foodborne infections. Dickson and Anderson (1992) stated that a variety of antimicrobial treatments for broiler carcasses have been investigated, with a primary focus on those that are to be practical and effective.

Antimicrobials help reduce microbial contamination on carcasses and inhibit the cell survival and reproduction of bacteria. For the antimicrobials to be effective in the facilities, they first must be approved by the USDA-FSIS, and must show efficacy against microorganisms. Compliance Guideline (2010), notes that the antimicrobial treatments must contain a certain concentration and must have a specific contact time between the wash and the carcasses. Treatments must also take into consideration the cost effectiveness and minimal adverse effect on the quality of final products. A few examples of antimicrobials approved for processing facilities are chlorine, inorganic acids, and organic acids (Bodler, 1997). This includes acetic and lactic acid, chicxide (lactic/ citric acid blend), and peracetic acids (Bolder, 1997). The industry has such a variation of treatments processors are using. More processing plants tend to use chlorine and organic acids since they are more effective. However, most antimicrobials have not been studied under mobile processing slaughter conditions (Killinger et al., 2010).

One of the most common antimicrobial treatments for decontamination of poultry is chlorine, it's used because it is inexpensive, safe, and easy to used (White, 1998; Northcutt and Jones, 2004). 
When chlorine is the treatment, it must be mixed in with water at optimal temperatures and contain a certain concentration. In addition to chlorine in the poultry processing water, the USDA-FSIS requires a certain concentration, used in parts per million, allows levels of 20-50 ppm (USDAFSIS, 2003). Efficacy of chlorine for bacterial reduction will decrease with an increase in $\mathrm{pH}$ and the organic load (Byrd and McKee, 2005). However when comparing chlorine to other treatments, no other treatments have been able to replace chlorine (Northcut et al., 2007). Chlorine used at maximum level of $50 \mathrm{ppm}$, around a 1-log microbial reduction is seen (James et al., 1992). Although chlorine levels are not to exceed $50 \mathrm{ppm}$, Salmonella spp. were eradicated from poultry carcasses with treatments of 300-400 ppm but not with $50 \mathrm{ppm}$ with chlorine treatment (Teotia and Miller, 1975; Bautista et al., 1997). However, McKee (2011) stated that for chlorine to be effective, there must be at least a contact time of 1 to 1.5 hours. A study done by Northcutt et al., (2007) recovered 6.3 and $3.9 \log _{10} \mathrm{CFU} / \mathrm{mL}$ on control carcasses for Campylobacter and Salmonella; after washing with sodium hypochlorite Campylobacter and Salmonella populations recovered were 1.6 and $2.4 \log _{10}$ lower than the control carcasses. Chlorine concentration levels will vary in the industries when comparing it to acid antimicrobial treatments.

Acid is used to destroy bacteria by penetrating through the cell and disrupting their cell membrane (Mani-Lopez et al., 2012). The acid molecule dissociates, this then further acidifies the cells interior, destroying the bacteria cells (Marriott, 2006). Organic acids have been investigated due to their bactericidal activity and because they are generally recognized as safe (GRAS) (Dickson 1992; Izat et al., 1989; Thomson et al., 1967). These specific types of acids are known for antimicrobial properties and their treatments have continuously been used throughout poultry processing. 
In studies, organic acid treatments are found to be more effective before the bacteria are attached to the surface of the carcasses. Acid concentrations that had $\geq 4 \%$ were required to kill $\geq 2$ $\log$ reduction of cells that were attached to broiler skins (Tamblyn and Conner, 1997). As previously noted, acids have been combined with other antimicrobial treatments in order to help lower the levels while assuring the efficacy of bacterial reduction. McKee (2011) conducted a survey and found that the most prevalent chemical used in post-chill applications in the industry was peracetic acid (PAA). This is a mix of an organic acid, which acetic (acetic acid) and an oxidant mixed (hydrogen peroxide) (Mani-Lopez et al., 2012). In regards of reduction, this antimicrobial treatment (PAA) reported a greater than a 3-log reduction when compared to using other individual antimicrobials (Bauermeister et al., 2008). Chen et al., (2014) found that 0.007 and $0.1 \%$ PAA had the greatest reductions on Salmonella and Campylobacter, of approximately 1.5 and $1.3 \log$ - reductions. Although in a study by Laury et al., (2009) found that spraying carcasses for 5 seconds with Chicxide had resulted in a reduction of $1.3 \log \mathrm{CFU} / \mathrm{mL}$, whereas immersing 5 seconds resulted in a $2.3 \log \mathrm{CFU} / \mathrm{mL}$ reduction. Lactic acid has shown effectiveness as an antimicrobial intervention and is commonly used (Hamby et al., 1987; Hardin et al., 1995). Anang et al., (2007) used a 10 minute time with $2 \%$ lactic acid dip and observed a $1.17 \mathrm{log}$ reduction of Salmonella enteritidis on chicken breasts. However, further evaluation of organic acids may help provide an economical and effective mean in controlling bacteria during poultry processing (Tamblyn and Conner, 1997).

Reducing microbial contamination may better be achieved through chemical applications during post-chilling as opposed to pre-chilling interventions. There has been an increase in poultry processing facilities that are using post-chilling antimicrobial interventions (McKee, 2011). Postchill application is one of the newer strategies used in the poultry processing industry, this 
application is applied immediately after the products leave the primary chiller (McKee, 2012). This method is used as a last resort to defend against pathogens before broilers leave the chilling system. This technique has a short time-period and higher concentrations of antimicrobials and is less expected to affect the quality of the final product and its quality. Furthermore, post-chilling has advantages over pre-chilling since the carcasses will be the cleanest, since the organic matter on the carcasses are lower during this period. In theory, respectively, bacteria can be greater reduced more effectively.

\subsection{Conclusions}

The abnormally high numbers of foodborne pathogens present on broiler carcasses is increasing every year. A target of 2-log reduction in bacterial counts to help eliminate or reduce Salmonella, most common pathogen on poultry products. Considering Salmonella continues to be a major cause food borne illness, despite the USDA regulations have become stricter. In the poultry processing industry, frequent contamination is occurring. Industries are trying to better understand what can be done to prevent these pathogens from spreading. Despite the variety of options available, studies have shown that antimicrobial treatments, may be the most suitable intervention in the processing plants.

In more recent years, some intervention strategies have been implemented. Post-chilling decontamination tanks have been able to provide a substitute for pathogen reduction during poultry processing (McKee, 2011). While the efficacy of antimicrobials has been validated against Salmonella, further studies can incorporate chillers to identify if it will be beneficial for the industries as well as for the consumers. 


\subsection{Study Objectives}

Objective 1: Evaluating the prevalence of Salmonella spp. and aerobic plate counts (APC), Escherichia coli, total coliforms (TCC), and yeast and molds on broiler carcasses from a small, local, USDA- Inspected Facility in West Virginia

Objective 2: Evaluating the efficacy of commercial antimicrobials against Salmonella cells that were either unstressed or cold-stressed and non-pathogenic surrogate Enterococcus faecium on broiler carcasses and wings 


\subsection{Introduction}

The Centers for Disease Control and Prevention (2011) estimated that each year in the United States, approximately 48 million people are affected and suffer from food-borne illnesses. Contaminated poultry meat is one of the most common food products that creates a public health concern. Salmonella and Campylobacter spp. are the two food-borne pathogens most commonly associated with poultry meat products (Nagel et al., 2013). Of these two foodborne pathogens, Salmonella is more common (Scallan et al., 2011). Out of all the illnesses attributed to poultry, Salmonella is responsible for $35 \%$ of illnesses (Batz et al., 2011). Salmonella spp. associated with poultry meat account for an estimated 9.4 million illnesses a year, leading to 55,961 hospitalizations and 1,351 deaths annually in the United States (Scallan et al., 2011).

Since 2011, new performance standards have been settled by the United States Department of Agriculture-Food Safety and Inspection Service (USDA-FSIS) in response to baseline studies that require routine testing (USDA-FSIS, 2010). These performance standards require routine testing for Salmonella in all processing plants to ensure that positive samples remain below an average of 7.5\% (USDA-FSIS, 2010). Studies conducted by Scheinberg et al., (2013) and Trimble et al., (2013) evaluated the presence of foodborne pathogens in chicken products and verified the presence of Salmonella spp. ranged from $28-45 \%$. Other studies can evaluate the prevalence of these foodborne pathogens and lead to best practices to prevent contamination during processing and packaging.

Bacterial contamination of poultry carcasses during processing is undesirable, but unavoidable (Tamblyn and Conner, 1997). With high percentages of Salmonella present, 
processing plants need to reduce or eliminate these pathogens before these products reach the consumers (Tamblyn and Conner, 1997). Although, there is no generally accepted and applicable method to reduce these specific pathogens causing illnesses, slaughtering facilities must somehow prevent such bacteria contamination (Bolder, 1997). Eliminating or decreasing pathogen counts, especially Salmonella in meat products post-harvest, can be resolved by different physical as well as antimicrobial treatments suggested by Mani-Lopez et al., (2011). Processing plants use various antimicrobial treatments ranging from a simple water wash to the application of organic acids, or mixes of various acids, and chlorine treatments. Commercial treatments such as lactic acid, peroyxacetic acid, and sodium hypochlorite are just a few antimicrobials approved by USDA-FSIS for use in decontaminating poultry carcasses (USDA-FSIS, 2017). Current, available data on industry scale poultry processing demonstrates that various commercial antimicrobials control Salmonella in poultry meat processing (Oyarzabal, 2005; McKee, 2011, 2012; Russel, 2012).

Recently, pathogen-control interventions during processing have changed and will continue to change with new laboratory advances. Real poultry processing facilities do not allow the use of pathogens for validity testing due to the biosafety concern. The use of surrogates and the fact that they are a helpful approach was considered by Bianchini et al., (2014) and Boney and Moritz (2016) to study the behavior and see if Enterococcus faecium mimicked Salmonella and can be used in future studies. The studies reviewed focus on various antimicrobial treatments or strategies that combine approved antimicrobials with pre- and post-chilling environments to eliminate specific foodborne pathogens on broiler carcasses and produce safe products for consumers. The objective of the study is to determine prevalence of Salmonella spp., APC's, TCC's, E. coli, and yeast and molds. The second part of the study evaluates the antimicrobial efficacy of peroxyacteic acid, lactic acid, lactic/ citric acid blend, and sodium hypochlorite against 
unstressed and cold-stressed adapted Salmonella and non-pathogenic Enterococcus faecium on broiler carcasses and wings. 


\subsection{Materials and Methods}

\subsection{Microbial Quality and Welfare of Broiler Carcasses}

A study consisted of 42 fresh then frozen broiler carcasses obtained from a small West Virginia Department of Agriculture Meat and Poultry Inspection Division facility (MPID). Broilers carcasses were processed by a USDA-FSIS facility in the state of Maryland. Whole chickens were transported to the state of West Virginia, where whole chickens were sold at the local Morgantown, WV Farmers Market. Whole chickens were purchased and delivered in coolers back to the Food Microbiology lab at West Virginia University. The broiler carcasses were stored at $-25^{\circ} \mathrm{C}$, they were thawed at $4^{\circ}$ for $48-72$ hours for analysis. Following thawing, whole carcasses were placed in $400 \mathrm{~mL}$ of Buffered Peptone Water (BPW, Hardy Diagnostics, MD, USA) and vigorously shaken for 60 seconds in a sterile poultry rinse bag (Nasco, Fort Atkinson, WI, USA) (Scheinberg et al., 2013). The rinsate was plated on $3 \mathrm{M}^{@} \mathrm{APC}, E$. coli $/ \mathrm{TCC}$, and yeast/ mold petrifilims ( 3 M Microbiology Products, St. Paul, MN, USA) for enumeration of the total aerobic bacteria, generic E. coli, coliforms, and fungi. Petrifilms were hand counted after incubation at 25 ${ }^{\circ} \mathrm{C}$ for 72 hours (APC), $35^{\circ} \mathrm{C}$ for 48 hours (E. coli/ TCC), and $25^{\circ} \mathrm{C}$ for 120 hours (yeast/mold).

The remaining rinsate, approximately $\sim 390$ to $395 \mathrm{~mL}$, was incubated at $35^{\circ}$ fir a 24 hour period. From the incubated solution, one tenth of the pre-enrichment was transferred to $10 \mathrm{~mL}$ Rappaport Vassiliadis (RV, Hardy Diagnostics, MD, USA). RV tubes were placed into a $42{ }^{\circ} \mathrm{C}$ incubator for 24 hours. From the RV tubes, a loop-full of incubated enrichment was streak plated onto Xylose Lysine Tergitol 4 (XLT-4) and HardyCHROM ${ }^{\mathrm{TM}}$ agar (Hardy Diagnostics, MD, USA). Plates were placed into the incubator at $35{ }^{\circ} \mathrm{C}$ for 24 hours. After incubation, 1-3 presumptive Salmonella colonies the XLT-4 and HardyCHROM ${ }^{\mathrm{TM}}$ were confirmed using the Oxoid 
Salmonella Latex Agglutination test kit (Oxoid Ltd, Baskingtoke, Hampshire, UK). Another confirmation test, API 20E test kit (BioMerieux, Durham, NC, USA) was used. Salmonella typhimurium ATCC 14028 was used at the positive control for the biochemical and immunological tests.

\subsection{Salmonella and Enterococcus inoculum preparation}

Salmonella Typhimurium ATCC 14028, Salmonella Tennessee ATCC 10722, and Enterococcus faecium ATCC 8459 were used in this study. Each Salmonella strain were maintained on Xylose Lysine Tergitol 4 (XLT-4) agar (Hardy Diagnostics, MD, USA). Whereas, the Enterococcus strains were maintained on Bile Esculin agar (Hardy Diagnostics. MD, USA). These two agars were stored at $4^{\circ} \mathrm{C}$. Regarding preparation of unstressed and cold-stress cells, the procedures are described by Shen et al., (2010). Unstressed cells, single colonies of each Salmonella and Enterococcus strains, were inoculated into $10 \mathrm{~mL}$ of Tryptic Soy Broth (TSB; Hardy Diagnostics, MD, USA) and incubated at $35^{\circ}$ for 24 hours. Subcultures and $0.1 \mathrm{~mL}$ of the 24 hour suspension were added to $10 \mathrm{~mL}$ of TSB and incubated for an additional 24 hours at 35 ${ }^{\circ} \mathrm{C}$. To prepare the cold-stress cells, previous subculture was triplicate-washed in a $10 \mathrm{~mL}$ tube of 0.1\% Buffered Peptone Water (BPW; Becton Dickinson and Company, Sparks, MD, USA), the mix was re-suspended in $10 \mathrm{~mL}$ of TSB and stored in a refrigerated setting at $4^{\circ} \mathrm{C}$ for 7 days. Previously, two Salmonella cultures were combined, and this mixture was centrifuged (VWR Symphony 4417, VWR International, Radnor, PA; 5,000 $\times$ g, 15 minutes). Following centrifugation, a duplicate wash was done with $0.1 \% \mathrm{BPW}$ to remove any broth remaining in the tube. Cultures were centrifuged once more and re-suspended in $0.1 \%$ BPW. Enterococcus cultures were prepared similarly. This preparation resulted in a final inoculum suspension of $\sim 8 \log$ CFU/mL of Salmonella and Enterococcus. 


\subsection{Broiler carcasses and wings collection and inoculation}

Broiler carcasses and skin-on wings were collected from the same processor that is a USDA-MPID in Maryland. An average of 800 pasture-raised cage-free birds and each year. Processing included: stunning, exsanguination, single stage static scalding, evisceration on stainless-steel table, and a wash bath. The wash was composed of an antimicrobial agent, a citricand lactic-acid based blend, before the carcasses were placed in a static container with ice water for 24 hours. In terms of the skin-on wings, they were manually removed by cutting them off the carcasses. As required by the USDA- MPID, the whole carcasses and wings were kept in a cooler, transported back to the West Virginia University Food Microbiology lab, where they remained in the walk in freezer for 24-72 hours until the experimentation. Broiler carcasses and skin-on wings were thawed at $5^{\circ} \mathrm{C}$ in a walk-in cooler for $48-72$ hours depending on thawing time. Carcasses and wings were randomly assigned to a treatment and were inoculated with unstressed and coldstress adapted Salmonella and Enterococcus based on the experiment procedure noted by Scott et al., (2015a). As for the carcasses and wings, both sides (all surface area) were spot inoculated with 5 drops of $200 \mu \mathrm{L}$ of the bacterial suspension. Mixture was spread over both sides of the carcasses and wings using an L spreader ( $\mathrm{L}$ shaped spreader, Hardy Diagnostics, MD, USA). Immediately after inoculation, carcasses and wings remained under a biohazard hood at ambient temperature for 20 minutes. This allowed time for cell attachment to the skin surface. Bacterial suspension was also spread plated on to agars. Plates were counted to identify what the final target inoculum. Final target inoculation on carcasses and wings ranged from $\sim 5.5$ to $6.5 \log \mathrm{CFU} / \mathrm{mL}$.

\subsection{Antimicrobial treatment of broiler carcasses and wings}

Inoculated broiler carcasses and wings were left untreated (control), followed by four treatments: peroxyacetic acid (PAA, 0.1\%, $\mathrm{pH} 3.0,15.7^{\circ} \mathrm{C}$. Birko, CO, USA), lactic acid (LA, 
$5 \%, \mathrm{pH} 2.0$, Birko, CO, USA), lactic and citric acid blend (LCA, 2.5\%, Chicxide, Birko, CO, USA), and sodium hypochlorite ( $\mathrm{SH}$, free available chlorine, 67-69 ppm, pH 9.41, $14.4{ }^{\circ} \mathrm{C}$, Birko, $\mathrm{CO}$, USA). Treatment included immersing four wings into a 3 -liter solution and three carcasses into a 10-liters solution. Dip treatments of antimicrobial solutions were applied agitation ( $~ 500$ $\mathrm{rpm}$ ) for 30 second periods. Carcasses were not drained, whereas wings received a 2-minute period to drain. Tested concentrations of all antimicrobials, except, chlorine, was the highest level allowed in the USDA-FSIS Directive 7120.7 (USDA-FSIS, 2017). Antimicrobial concentrations for PAA, LA, LCA were calculated per the supplier's fact sheet. In regarding chlorine concentrations, treatment concentration based off SH concentration used during poultry processing, which is 50 ppm of free chlorine; however, it is unclear whether the initial chlorine or residual concentration. This is concerning due to the instantaneous reaction between the chlorine and organic matter. Consequently, a slightly higher concentration of chlorine, ranging from $67.69 \mathrm{ppm}$ was used. Residual free chlorine concentrations were examined and noted. Carcasses ranged from 11.8 to $28.0 \mathrm{ppm}$ for wings, after 20 second dip treatment, based on the chlorine measurement using the DPD-method (Shen et al., 2013).

\subsection{Microbial analysis}

Total aerobic plate counts, for both Salmonella and Enterococcus populations were analyzed. Following antimicrobial treatment, carcasses were rinsed in $400 \mathrm{~mL}$ of BPW, supplemented with $0.1 \%$ sodium thiosulfate (Fisher Scientific, Springfiled, NJ, USA). Carcasses were individually placed into sterile chicken-rinse bags, they were vigorously shaken (manually) for a 60 second period. Individual wings were placed in a sterile Whirl-Pak ${ }^{@}$ (Nasco. Fort Atkinson, WI, USA), containing $150 \mathrm{~mL}$ of BPW supplemented with $0.1 \%$ sodium thiosulfate. Each bag containing a wing was vigorously shaken for 60 seconds. Broiler carcasses and wings 
were shaken to ensure cells can detach from skin surface to determine survival or reduction of unstressed or cold-stress adapted cells. Following rinsing, BPW mixtures were plated onto four different media. Tryptic Soy Agar (TSA) was used for aerobic plate counts, XLT-4 and HardyCHROM $^{\mathrm{rm}}$ agar was used to grow Salmonella; whereas Bile Esculin agar grew Enterococcus. Plates were incubated for 24 hours before counting using the counter in the laboratory.

\subsection{Data analysis}

Studies were repeated twice; 4 wings and 3 carcasses per treatment replication were used. This approach brought the total of 8 wings per treatment and 6 samples for carcasses per treatment. Experiments were conducted on a completely randomized $5 \times 2$ factorial design. Five treatments with two stress-type cells, unstressed and cold-stressed account for this design. A Mixed Model Procedure of SAS (version 9.2, SAS, Cary, NC) was used. Analyzing the survival and reduction of Salmonella and Enterococcus. The experimental model included the data analyzing individual factors such as antimicrobial treatment, cell stress type, and their interactions. Comparing the level of reduction between the Salmonella and Enterococcus and their responses to the different antimicrobial treatments, the Mixed Model Procedure used individual factors of the bacterial medium, the treatments used, the cell stress type, and all possible interactions of the study. Reduction data was determined by using a reduction ratio of $\log _{10}\left(\mathrm{~N}_{0} / \mathrm{N}\right)$. $\mathrm{N}_{0}$ states the average control plate counts, whereas the $\mathrm{N}$ accounts for the plate count of each individual antimicrobial treated sample. The means were compared using $\alpha=0.05$ significance level determined by Tukey HSD. 


\subsection{Results and Discussion}

Table 1 shows the populations recovered on APC, E. coli/ TCC, and yeast/molds from 42 samples. These results are hygienic indicators of the microbial quality of whole raw carcasses. The APC is ranged from 2.1 to $3.4 \log \mathrm{CFU} / \mathrm{mL}$ with an average of $2.6 \log \mathrm{CFU} / \mathrm{mL}$; whereas, the population of TCC ranged from 0.5 to $2.3 \log \mathrm{CFU} / \mathrm{mL}$ with an average of $1.1 \log \mathrm{CFU} / \mathrm{mL}$. Compared to a previous study done on whole chickens from a farmers' market and supermarket in Pennsylvania, investigators found that APC and TCC populations ranged from 2.6 to 4.2 and 0.8 to $1.5 \log$ CFU/g, respectively (Scheinburg et al., 2013). Total populations of yeast/molds ranged from 1.6 to $4.0 \log \mathrm{CFU} / \mathrm{mL}$, averaging $2.4 \log \mathrm{CFU} / \mathrm{mL}$. As a potential food safety hazard, yeast/molds may produce a mycotoxins that may have carcinogenic and immunosuppressive effects. Generic $E$. coli is used to assess potential fecal contamination on processed meat and poultry products per the USDA-FSIS (Scheinberg et al., 2013). In the current study, approximately $30 \%$ (12/42) of carcasses sampled tested positive for E. coli, with range of 0.5 to $1.7 \log \mathrm{CFU} / \mathrm{mL}$; this level is comparable to previous studies of Scheinberg et al., (2013) and Northcutt et al., (2006). Although levels of APC and E. coli/TCC on theses carcasses from the USDA-MPID are not greater than the previous study, it is still a concern for small broiler processors to apply a post-harvest interventions to further reduce background microflora that remains on broiler surfaces.

\subsection{Salmonella spp. prevalence on broiler carcasses.}

A total of 42 broiler carcass samples were used and evaluated for the presence/ absence of Salmonella spp. using API 20E strips with biochemical profile 6704752 (Levy et al., 2014). Further confirmation of Salmonella was done with the Latex Agglutination test. The frequency of Salmonella detection (29\%) in this study is lower than a previous study that surveyed carcasses 
from a small USD-IF in the southeastern United States; $43 \%$ were positive for Salmonella with $8 \%$ positive from Cornish Cross and 78\% positive from Red Ranger birds (Trimble et al., 2013). Current results are comparable to findings from a study conducted in Pennsylvania where $28 \%$ were Salmonella positive from the farmers' market and $20 \%$ were positive from local organic farms at the supermarkets (Scheinberg et al., 2013). Occurrence of Salmonella present on small, locally processed broilers may be attributed to lack of farm management, regulatory guidelines, insistence on minimal antimicrobial application, and a single static chilling tank. Our results provide an important preliminary baseline dataset for frequency of detection for Salmonella on USDA-IF broilers produced in West Virginia. This data justifies development of post-harvest control strategies that use a post-chilling dipping treatments mixed with an antimicrobial agent.

\subsection{Efficacy of antimicrobials to inactivate aerobic plate counts and Salmonella}

Total aerobic plate counts were determined using TSA (Table 1). Aerobic plate count for untreated, unstressed, and cold-stressed adapted Salmonella, inoculated on whole broiler carcasses and wings, ranged from 6.0 to $6.3 \log \mathrm{CFU} / \mathrm{mL}$. Carcasses with antimicrobial treatments showed a main effect $(P=0.001)$ despite the type of stress $(P=0.947)$, and an interaction treatment and the cell stress type. Although for wings, the individual factors analyzed and the interactions were statistically significantly $(P<0.05)$. A difference of 0.2 to $0.3 \log$ units in various comparison is not considered microbial relevance (Scott et al., 2015b). Of the various antimicrobials tested, reductions in aerobic plate counts ranged from 0.7 to $2.3 \log \mathrm{CFU} / \mathrm{mL}$ on carcass and 0.6 to 1.7 $\log / \mathrm{CFU} / \mathrm{mL}$ on wing samples inoculated with unstressed or cold-stressed cells. Samples treated with $0.1 \%$ PAA had the greatest $(P<0.05)$ reduction of aerobic plate counts on carcasses and wings. This difference ranged from 1.7 (unstressed) to 2.3 (cold-stressed) on carcasses; whereas, wings 
ranged from 1.4 (unstressed) to 1.7 (cold-stressed) $\log \mathrm{CFU} / \mathrm{mL}$, respectively. Other treatments, LA, LCA, and SH notably, had similar reductions on aerobic plate counts; results ranged from 0.7 to 0.9 and 0.6 to $1.1 \log \mathrm{CFU} / \mathrm{mL}$ for all carcasses and wings.

The efficacy of antimicrobial treatments was based on Salmonella recovery from XLT-4 and HardyCHROM ${ }^{\mathrm{TM}}$, Table 2 and 3, respectively. Antimicrobial treatment reduced $(P<0.05)$ Salmonella on carcasses and wings for stressed microorganisms. Interactions between antimicrobial treatments and stress cell type showed significance $(P<0.05)$ on the HardyCHROM ${ }^{\mathrm{TM}}$ agar, but showed no significance on the XLT-4 agar. Cold-stress adapted Salmonella cells were more sensitive $(P<0.05)$ to antimicrobial treatment compared to unstressed cells on both broiler carcasses and wings. As an indication of Salmonella load, control broiler carcass counts ranged from 5.4 to $5.6 \log$ CFU/mL of both unstressed and cold-stress adapted Salmonella.

Unstressed Salmonella counts were obtained from broiler carcasses that had been treated with PAA, LA, LCA, and SH for 30 seconds. Reductions ranged from 0.9 to $1.7 \log \mathrm{CFU} / \mathrm{mL}$ and 0.6 to $1.5 \log \mathrm{CFU} / \mathrm{mL}$, respectively, for counts determined with XLT-4 and HardyCHROM ${ }^{\mathrm{rM}}$ agars. The same treatments produced a greater $(P<0.05)$ reduction of cold-stress adapted Salmonella cells on carcasses. Carcasses levels were 1.3 to $2.1 \log$ CFU/mL on XLT-4 and 1.1 to $1.8 \log \mathrm{CFU} / \mathrm{mL}$ on $\mathrm{HardyCHROM}{ }^{\mathrm{TM}}$. In comparison, wings showed similar results; antimicrobial dipping treatments reduced $(P<0.05)$ cold-stressed Salmonella cells; cold-stressed reductions ranged from 0.9 to $1.7 \log \mathrm{CFU} / \mathrm{mL}$ and unstressed was comparable with 0.5 to $1.3 \log \mathrm{CFU} / \mathrm{mL}$. Cold-stress cells were more susceptible to interventions; these findings agree with previous studies carried out by Semancheck and Golden (1998) and Shen et al., (2011). This sensitivity is due to the increasing amount of unsaturated fatty acids across the cell membrane and the reduction of their melting point after adapting to cold-stress. Results suggested that the chilling process 
generated cold-stress adapted pathogenic cells on poultry surfaces; this adaption to cold-stress might increase the efficacy of post chilling, antimicrobial dipping treatments.

Among antimicrobial treatments, PAA was the most effective $(P<0.05)$ for reducing Salmonella on carcasses and wings (Table 3 and 4). Other treatments, lactic acid, lactic/citric acid blend, and sodium hypochlorite, produced similar results and were less effective compared to PAA. PAA had reduced unstressed cells by $1.5 \log$ CFU/mL on HardyCHROM ${ }^{\mathrm{TM}}$ and by $1.7 \log$ $\mathrm{CFU} / \mathrm{mL}$ on XLT-4; reductions of $1.5 \log \mathrm{CFU} / \mathrm{mL}$ on HardyCHROM ${ }^{\mathrm{TM}}$ to $1.7 \log \mathrm{CFU} / \mathrm{mL}$ on XLT-4, in respects of carcasses (Table 3 ) and wings (Table 4). Sensitivity of cold-stressed cells to PAA was greater; the reduction level was increased to $1.8\left(\right.$ HardyCHROM $\left.^{\mathrm{rM}}\right)$ and 2.1 (XLT-4) $\log$ CFU/mL on carcasses and 1.5 (HardyCHROM $^{\mathrm{TM}}$ ) and 1.7 (XLT-4) $\log$ CFU/mL on wings. PAA, which is combination of peracetic acid and hydrogen peroxide, is approved by USDA-FSIS for application of poultry carcasses during post-chill dipping at concentrations no greater than 2,000 parts per million (ppm) (0.2\%) (McKee, 2011). Nagel et al., (2013) reported that 0.1\% PAA reduced naldixic acid resistant-Salmonella by $2.3 \log \mathrm{CFU} / \mathrm{mL}$ on broiler carcasses in a pilot plant, chilling tank at a 20 second dwelling time. A recent study from the same research group found that $0.1 \%$ PAA achieved a $1.5 \mathrm{log}$ reduction of Salmonella on post-chilled ground chicken (Chen et al., 2014). Scott et al., (2015a) reported that $0.007 \%$ (700 ppm) PAA reduced Salmonella populations by $1 / 5 \log$ on chicken wings after a 20 second dipping treatment. The aforementioned studies stated that PAA $(0.04-0.1 \%)$, used during the post-chill dipping process, is the most effective antimicrobial to decontaminate Salmonella on poultry products. Even when comparing PAA to other commercially used products such as chlorine, lysozyme, and sulfuric acid. For small poultry producers in West Virginia and Pennsylvania, producers are more intrigued by use of PAA instead of chlorine to decontaminate foodborne pathogens. 
In the current study, broiler carcasses and wings treated with LA $(5 \%)$ had reduced unstressed Salmonella cells by 1.1 (HardyCHROM $^{\mathrm{TM}}$ ) to $1.3(\mathrm{XLT}-4 \log \mathrm{CFU} / \mathrm{mL}$ and 0.8 $\left(\right.$ HardyCHROM $^{\mathrm{TM}}$ ) to $1.1(\mathrm{XLT}-4) \log \mathrm{CFU} / \mathrm{mL}$, respectively (Table 3 and 4). In terms of coldstressed cells, higher $(P<0.05)$ reductions of $1.7 \log$ CFU/mL (on both HardyCHROM ${ }^{\mathrm{T} M}$ and XLT4) and $1.4\left(\right.$ HardyCHROM $\left.^{\top M}\right)$ to $1.7(\mathrm{XLT}-4) \log \mathrm{CFU} / \mathrm{mL}$ were observed on inoculated broiler carcasses and wings, compared to unstressed cells. LA is currently used to reduce Salmonella on retail poultry and meats produced since USDA-FSIS issued a pathogen reduction standard for Salmonella in 1994 that allowed concentration $\leq 5 \%$ for pre- and post-chilling of animal carcasses (Laury et al., 2009). An earlier study (Izat et al., 1990), found that 1\% of LA in chilling and scalding water reduced Salmonella Typhimurium below the detectable limit. A study by Yang et al., (1998) sprayed 2\% LA on carcasses, obtaining a 2 log-reduction of Salmonella per carcass. Killinger et al., (2010) also studied the efficacy of a $2 \%$ LA rinse on chicken wings. Authors observed a greater than 5 log-reduction in inoculated Salmonella. For the current study, an approximately 1-2 log-reduction of Salmonella was observed; meeting expectation since there was only a 30 second dip time. This was compared to another study by (Killinger et al., 2010), who used a 3 minute treatment.

In the present study and for unstressed Salmonella_cells, LCA blend and SH treatments produced similar reductions $(P>0.05)$ of 0.6 to $0.7\left(\right.$ HardyCHROM $\left.^{\mathrm{TM}}\right)$ to 0.9 to $1.1(\mathrm{XLT}-4) \log$ $\mathrm{CFU} / \mathrm{mL}$ for carcasses; reductions of 0.5 (HardyCHROM $^{\mathrm{TM}}$ ) to 0.8 to $1.0(\mathrm{XLT}-4) \log \mathrm{CFU} / \mathrm{mL}$ was observed on wings compared to the controls (Table 3 and 4). In terms of treatment effects on cold-stressed cells, an additional reduction $(P<0.05)$ of 0.3 to $0.8 \log \mathrm{CFU} / \mathrm{mL}$ was observed on carcasses and wings using XLT-4 and HardyCHROM ${ }^{\mathrm{TM}}$ agar (Tables 3 and 4). Recently, the use of chlorine in the poultry chillers has declined due to the reactivity of chlorine with organic matter 
(Shen et al,. 2016). Chlorine treatments require a high concentration and a long contact time, generating gas and trichloramines, hindering export to Russia (Chen et al., 2014). In small poultry processing facilities, interest in using chlorine is slowly decreasing due to expectation for natural and organic processes. Chicxide is a newly commercial blend of lactic/ citric acids; approved for use in poultry meats with a maximum concentration allowance of $2.5 \%$ according to USDA-FSIS (USDA-FSIS, 2005). Laury et al., (2009) reported that spraying Chicxide, on broiler carcasses for 20 seconds, reduced Salmonella by $1.3 \log \mathrm{CFU} / \mathrm{mL}$; dipping treatments resulted in $2.3 \log$, Salmonella reduction. Furthermore, these authrors indicated the Chicxide results were comparable to chlorine. The aforementioned study suggests that a lactic- and citric acid based antimicrobial agent could be beneficial in applying post-chilling treatments for small scale poultry processors.

\subsection{Efficacy of antimicrobials to inactivate Enterococcus faecium}

Response of unstressed and cold-stressed, adapted Enterococcus faecium to various antimicrobial treatments was evaluated. Overall, dipping broiler carcasses into four antimicrobials reduced unstressed Enterococcus faecium populations by 0.2 to $1.7 \log \mathrm{CFU} / \mathrm{mL}$; whereas a 1.0 to $2.0 \log \mathrm{CFU} / \mathrm{mL}$ reduction on wings, compared to the untreated control sample was observed (Table 5). As for the cold-stressed cells on carcasses, they appeared to be more susceptible $(P<0.05)$ to antimicrobials than unstressed cells with reductions increasing to 1.0 to $2.0 \mathrm{log}$ $\mathrm{CFU} / \mathrm{mL}$. Lactic acid resulted in an additional of $0.3 \log \mathrm{CFU} / \mathrm{mL}$ reduction of cold-stressed cells on wings compared to unstressed cells. Salmonella observations were similar for unstressed or cold-stressed-adapted Enterococcus cells on carcasses and wings; order of antimicrobial efficacy was: $\mathrm{SH} \leq \mathrm{LCA}<\mathrm{LA}<\mathrm{PAA}$. As an example and compared to the control, PAA reduced levels of Enterococcus faecium by 1.7 to $2.0 \log \mathrm{CFU} / \mathrm{mL}$ on carcasses and wings for unstressed or coldstressed adapted cells (Table 5). 
Enterococcus faecium has been evaluated as a safer alternative to study Salmonella for thermal lethality validation studies in almonds (Jeong et al., 2011) and in a balanced carbohydrate protein meal (Bianchini et al., 2014). However, this Salmonella surrogate has not been studied of evaluated on poultry products, and there is limited information on appropriate Salmonella surrogates during poultry processing. To draw valid conclusions about antimicrobial efficacy using surrogate microorganisms, the surrogate must survive the process at least as well or better than the target pathogen (Adler et al., 2016). The current study evaluates reductions of unstressed or coldstressed adapted Salmonella and Enterococcus faecium on broiler carcasses and wings from various antimicrobial treatments (Tables 6 and 7). Because TSA support medium permits growth of other microorganisms, TSA counts were not used for comparison in this study.

Application of PAA, LA, LCA, and SH to carcasses reduced unstressed and cold-stressed Enterococcus faecium, and levels were not different or less than those for Salmonella. PAA reduced counts by 1.7 and $2.0 \log \mathrm{CFU} / \mathrm{g}$ for unstressed and cold-stressed adapted Enterococcus faecium, respectively; this response is similar to Salmonella $(P<0.05)$ reductions that ranged from 0.2 to $0.5 \log \mathrm{CFU} / \mathrm{mL}$ for unstressed cells and from 1.0 to $1.4 \log \mathrm{CFU} / \mathrm{mL}$ for cold-stressed adapted for Enterococcus faecium compared to the unstressed 0.6 to $1.3 \log \mathrm{CFU} / \mathrm{mL}$ on XLT04 and HardyCHROM ${ }^{\mathrm{Tm}}$; Table 6). Reductions of unstressed Enterococcus faecium on wings treated by the antimicrobials were greater $(P<0.05)$ than Salmonella reductions on HardyCHROM ${ }^{\mathrm{TM}}$ agar; although, results were similar $(P>0.05)$ to the count for XLT-4 agar when lactic acid or the lactic/citric acid was used (Table 7). Cold-stressed Enterococcus faecium on wings behaved similar $(P>0.05)$ to cold-stressed adapted Salmonella after being exposed to the antimicrobials; reductions of 1.0 to $1.9 \log \mathrm{CFU} / \mathrm{mL}$, determined with Bile Esculin agar, were observed. Salmonella reductions of 1.1 to $1.7 \log \mathrm{CFU} / \mathrm{mL}$ and 0.9 to $1.5 \log \mathrm{CFU} / \mathrm{mL}$ were observed with 
XLT-4 HardyCHROM ${ }^{\mathrm{TM}}$ agar, respectively (Table 7). Enterococcus faecium could serve as a surrogate for Salmonella validating antimicrobial interventions during broiler processing.

In conclusion, results of the current study confirmed that applying a post-chilling antimicrobial dipping treatment, primarily PAA, could be used an intervention approach to control Salmonella on locally processed broilers. Cold-stressed adapted Salmonella cells are more susceptible to antimicrobials than the unstressed cells. This is due to the cell walls being more susceptible to antimicrobials and deteriorate more easily. Enterococcus faecium serve as a potential nonpathogenic surrogate for Salmonella in in-plant validation studies for local, small poultry processors. These results suggest options for development of USDA-FSIS; 5 year strategic plan for Salmonella control in poultry meat products (USDA-FSIS, 2013). This data can assist local and state regulatory agencies in reducing potential risk of Salmonella in locally grown poultry products. 


\subsection{References}

1. Anang, D. M., Rusul, G., Bakar, J., and Ling, F. H. (2007). Effects of lactic acid and lauricidin on the survival of Listeria monocytogenes, Salmonella enteritidis, and Escherichia coli $0157: \mathrm{H} 7$ in chicken breast stored at $4{ }^{\circ} \mathrm{C}$. Food Control. 18:961-969.

2. Adler, J., E. Cain-Helfrich, and C. Shen. 2016. Reductions in natural microbial flora, generic escherichia coli and pathogenic salmonella on jalapeno peppers processed in a commercial antimicrobial cabinet-a pilot plant trial. J. Food Prot. 79:1854-1859.

3. Batz, M. B., S. Hoffmann, and J. G. Morris, Jr. 2011. Ranking the risks: the 10 pathogenfood combinations with the greatest burden on public health. University of Florida, Emerging Pathogens Institute. https://folio.iupui.edu/bitstream/handle/ 10244/1022/72267report.pdf.

4. Bauermeister, L.J., J.W. Bowers, J.C. Townsend, and S.R. McKee. 2008a. Validating the efficacy of peracteic acid mixture as an antimicrobial in poultry chillers. Journal of Food Protection. 71:119-122.

5. Bauermeister, L.J., J.W. Bowers, J.C. Townsend, and S.R. McKee. 2008b. The microbial and quality of properties of poultry carcasses treated with peracetic acid as antimicrobial treatment. Poultry Science. 87:2390-2398.

6. Bautista, D., Sylvester, N., Barbut, S., and Griffiths, M. (1997). 'The Decontamination Efficacy of Antimicrobial Rinses on Turkey Carcasses Using Response Surface Designs' in International Journal Food Microbiolgoy. 34, 279-292

7. Bianchini, A., Stratton, J., Weier, S., Hartter, T., Plattner, B., Rokey, G., Hertzel, G., Gompa, L., Martinez, B., and Eskridge, K. (2014). Use of Enterococcus faecium as a Surrogate for Salmonella enterica during Extrusion of a Balanced Carbohydrate-Protein Meal. Journal of Food Protection, 77(1), 75-82. doi: 10.4315/0362-028x.jfp-13-220

8. Bolder, N. (1997). Decontamination of meat and poultry carcasses. Trends in Food Science \& Technology, 8(7), 221-227. doi:10.1016/s0924-2244(97)01040-6

9. Boney, J. W., and J. S. Moritz. 2016. The effects of varying short term steam conditioning temperatures on the mitigation of Enterococcus faecium 8459, a nonpathogenic surrogate of Salmonella. Poult. Sci. 95:20.

10. Bourassa, D. V., Holmes, J. M., Cason, J. A., Cox, N. A., Rigsby, L. L., \& Buhr, R. J. (2015). Prevalence and Serogroup Diversity of Salmonella for Broiler Neck Skin, Whole Carcass Rinse, and Whole Carcass Enrichment Sampling Methodologies following Air or Immersion Chilling. Journal of Food Protection, 78(11), 1938-1944. doi:10.4315/0362-

11. Brashears, M. M., D. E. Burson, E. S. Dormedy, L. Vavak, S. R. McKee, W. Fluckey, M. Sanchez. 2001. HACCP implementation and validation in small and very small meat and poultry processing plants. Nebraska Dairy, Food and Environmental Sanitation. 21:20-28.

12. Busta, F. F., Suslow, T. V., Parish, M. E., Beuchat, L. R., Farber, J. N., Garrett, E. H. and Harris, L. J. (2003). The use of indicators and surrogate microorganisms for the evaluation of pathogens in fresh and fresh-cut produce. Comprehensive Reviews in Food Science and
Food Safety. 2:179-185. 
13. Byrd, J. A. and McKee, S. R. (2005). Improving slaughter and processing technologies. In: Mead, G. C. (Ed.), Food Safety Control in the Poultry Industry. CRC Press LLc, Boca Raton, FL, pp. 310-327.

14. Centers for Disease Control and Prevention. 2011. Fatal Laboratory-acquired infection with an attenuated Yersinia pestis strain- Chicago, Illinois, 2009. Morb. Mortal. Wkly. Rep. 60:201-205.

15. Centers for Disease Control and Prevention. 2011. Estimates of Foodborne Illness in the United States. Internet Address: http://www.cdc.gov/foodborneburden/2011-foodborneestimates.html.

16. Centers for Disease Control and Prevention. 2011. Vital Signs: Incidence and Trends of Infection with Pathogens Transmitted Commonly Through Food - Foodborne Diseases Active Surveillance Network, 10 U.S. Sites, 1996-2010. Available at: http://www.cdc.gov/mmwr/preview $/ \mathrm{mmwhhtml} / \mathrm{mm} 6022 \mathrm{a} 5 . \mathrm{htm}$ ?s cid=mm6022a5 w.

17. Centers for Disease Control and Prevention. 2014. Final update: Outbreak of Salmonella Heidelberg infections linked to Tyson brand mechanically separated chicken at a correctional facility. Available at: http://www.cdc.gov/salmonella/heidelberg-01-

18. Centers for Disease Control and Prevention. 2014. Human Salmonella Typhimurium infections linked to exposure to clinical and teaching laboratories. Available at: http://www.cdc.gov/salmonella/typhimurium-labs-06-14.

19. Channaiah, L. H., Holmgren, E. S., Michael M., Sevart N. J., Milke, D., Schwan, C. L., Krug, M., Wilder, A., Phebus, R. K., Thippareddi, H., and Milliken, G. (2016) Validation of Baking To Control Salmonella Serovars in Hamburger Bun Manufacturing, and Evaluation of Enterococcus faecium ATCC 8459 and Saccharomyces cerevisiae as Nonpathogenic Surrogate Indicators. Journal of Food Protection: April 2016, Vol. 79, No. 4, pp. 544-552.

20. Chen, X., L. J. Bauermeister, G. N. Hill, M. Singh, S. F. Bilgili, and S. R. McKee. 2014. Efficacy of various antimicrobials on reduction of salmonella and campylobacter and quality attributes of ground chicken obtained from poultry parts treated in a postchill decontamination tank. J. Food Prot. 77:1882-1888.

21. Compliance Guideline for Controlling salmonella and ... (2010, May 11). Retrieved November http://www bing com/cr? A269F169951.com/cr.1G=D966E5249271461C803CC40C4AEC3541\&CID=2CB7DF 4OvE 0 W Compliance_Guid $\mathrm{x}, 5087.1$

22. Devriese, L. A., Pot, B. and Collins, M. D. (1993). Phenotypic identification of the genus Enterococcus and differentiation of phylogenetically distinct enterococcal species and species groups. Journal of Applied Bacteriology. 75, 399-408.

23. Dickson, J. S. (1992). Acetic acid action on beef tissue surfaces contaminated with Salmonella typhimurium. Journal Food Science. 57:297-301.

24. Dickson, J. S. and M. E. Anderson, 1992. Microbiological decontamination of food animal carcasses by washing and sanitizing systems: A review. Journal of Food Protection. 55:133-140. 
25. Enache, L., Kataoka, A., Black, D. G., Napier, C. D., Podolak, R., and Hayman, M. M. (2015). Development of a dry inoculation method for thermal challenge studies in lowmoisture foods by using talc as a carrier for Salmonella and a surrogate (Enterococcus faecium). J. Food Protection. 78:1106-1112.

26. Enterococcus. (2017, August 24 $\left.4^{\text {th }}\right)$. Retrieved October 2 $2^{\text {nd }}, 2017$, from http://catalog.hardydiagnostics.com/cp prod/Content/hugo/Enterococcus.htm

27. Fanatico, A. (2003). Small-scale Poultry Processing. Retrieved April 15, 2016.

28. Fraser, S. L. (2017, September 19). Enterococcal Infections. Retrieved October 2, 2017, from htttp://emedicine.medscape.com/article/216993-overview

29. Friedly, E., Crandall, P. G., Ricke, S., O'Bryan, C. A., Martin, E. M., and Boyd, L. M. (2008). Identification of Listeria innocua surrogates for Listeria monocytogenes in hamburger patties. Journal of Food Sciecne. 73:M174-M 178.

30. FSIS. (2013, August 12). Retrieved November 29, 2017, from https://www.fsis.usda.gov/wps/portal/fsis/topics/rulemaking/!ut/p/a0/04_Sj9CPykssy0xP LMnMz0vMAfGjzOINAg3MDC2dDbz83RzdDDz9jN3CLPzcDQ28TfULsh0VAdZTe2 c! $/ ? 1 \mathrm{dmy}$ t=true\&urile $=\mathrm{wcm} \% 3 \mathrm{Apath} \% 3 \mathrm{~A} \% 2 \mathrm{Ffsis}-$ content $\% 2$ Finternet $\% 2$ Fmain $\% 2$ Ftopics $\% 2$ Fdata-collection-andreports $\% 2$ Fmicrobiology $\% 2$ Fannual-serotyping-reports $\% 2$ Fct_index

31. Galvez, A., Abriouel, H., Benormar, N., and Lucas, R. (2010). Microbial antagonists to food-borne pathogens and biocontrol. Current Opinion in Biotechnology, 21(2), 142-148. doi:10.1016/j.copbio.2010.01.005

32. Giraffa, G. (2002). Enterococci from foods. FEMS Microbiology Reviews, (26)2, 163-171. doi:10.1016/s0168-6445(02)00094-3

33. Giraffa, G., Carminati, D. and Neviani, E. (1997). Enterococci isolated from dairy products: a review of risks and potential technological use. Journal of Food Protection. 60 ,
$732-738$.

34. Greenberg, D. L., J. D. Busch, P. Keim, and D. M. Wagner. 2010. Identifying experimental surrogates for Bacillus anthracis spores: a review. Invest. Genet. 2010:4. doi:1186/20412223-1-4.

35. Hamby, P. L., Savell, J. W., Acuff, G. R., Vanderzant, C., and Cross, H. R. (1987). Spraychilling and carcass decontamination systems using lactic and acetic acid. Meat Science
21:1-14.

36. Hardie, J.M. and Whiley, R.A. (1997). Classification and overview of the genera Streptococcus and Enterococcus. Journal of Applied Microbiology Symposium Supplement. 83, 1S-11S.

37. Hardin, M. D., Acuff, G. R., Lucia, L. M., Oman, J. S., Savell, J. W. (1995). Comparison of methods for decontamination from beef carcass surfaces. Journal of Food Protection. 58:368-374.

38. Hu, M., and Gurtler, J. B. (2017). Selection of Surrogate Bacteria for Use in Food Safety Challenge Studies: A Review. Journal of Food Protection, 80(9), 1506-1536. doi:10.4315/0362-028x.jfp-16-536

39. Izat., A. L., Colberg, M., Adams, M. H., Reiber, M. A., and Waldroup, P. W. (1989). Production and processing studies to reduce the incidence of salmonellae on commercial broilers. Journal Food Protection. 52:670-673. 
40. Izat, A. L., M. Colberg, R. A. Thomas, M. H. Adams, and C. D. Driggers. 1990. Effects of lactic acid in processing waters on the incidence of Salmonella on broilers. J. Food Qual. 13: 295-306.

41. James, O. J., Brewer, R. L., Prucha, J. C., Williams, W. O., and Parham, D. R. (1992). 'Effects of Chlorination of Chill Water on the Bacteriological Profile of Raw Chicken

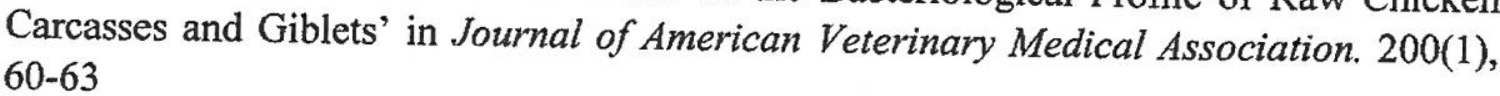

42. Jay, J. M. (2012). Modern Food Microbiology. Springer Science \& Business Media.

43. Jeong, S., B. P. Marks, and E. T. Ryser. 2011. Quantifying the performance of Pediococcus sp. (NRRL B-2354: Enterococcus faecium) as a nonpathogenic surrogate for Salmonella Enteriditis PT30 during moist-air convection hearing of almonds. J. Food Prot. 74:603609.

44. Killinger, K. M., A. Kannan, A. I. Bary, and C. G. Cogger. 2010. Validation of a 2 percent lactic acid antimicrobial rinse for mobile poultry slaughter operations. J. Food Prot. 73:2079-2083.

45. Kim, J. K, and M. A. Harrison. 2009. Surrogate selection for Escherichia coli 0157:H7 based on cryotolerance and attachment to romaine lettuce. Journal of Food Protection. 72:1385-1391.

46. Laury, A. M., M. V. Alvarado, G. Nace, C. Z. Alvarado, J. C. Brooks, A. Echeverry, and M. M. Brashears. 2009. Validation of a lactic acid- and citric acid-based antimicrobial product for the reduction of Escherichia coli 0157: $\mathrm{H7}$ and Salmonella on beef tips and whole chicken carcasses. J. Food Prot. 72:2208-2211.

47. Levy, D., N. Beck, A. Kossik, T. Patti, J. Meschke, M. Calicchia, and R. Hellberg. 2014. Microbial safety and quality of fresh herbs from Los Angeles, Orange County and Seattle farmers' markets. J. Sci. Food Agri. 95: 2641-2645.

48. Lillard, H.S. 1989. Factors affecting the persistence of Salmonella during the processing of poultry. J. Food Prot. 52:829-832.

49. Mani-López, E., García, H., \& López-Malo, A. (2012). Organic acids as antimicrobials to control Salmonella in meat and poultry products. Food Research International, 45(2), 713 721. doi:10.1016/j.foodres.2011.04.043

50. Marriott, N. G. and R. B. Gravani. 2006. Principles of Food Sanitation. Springer Science+Business Media, Inc, New York, NY.

51. McKee, S. R. (2011). Salmonella and Campylobacter Control during Poultry Processing. International Poultry Scientific Forum, Atlanta, Georgia. January 24-25, 2011.

52. McKee, S. R. (2012). Salmonella control in poultry processing. $65^{\text {th }}$ Annual Reciprocal Meat Conference, Fargo, ND, 17 to 20 June 2012.

53. Moreno, M. F., Sarantinopoulous, P., Tsakalidou, E., and Vuyst, L. D. (2006). The role of and application of Enterococci in food and health. International Journal of Food Microbiology, 106(1), 1-24. doi: 10.1016/j.ijfoodmicro.2005.06.026

54. Morrison, D., Woodford, N. and Cookson, B. (1997). Enterococci as emerging pathogens of humans. Journal of Applied Microbiology Symposium Supplement. 83, 89S-99S.

55. Murray, B. E. (1990) The life and times of the Enterococcus. Clinic Microbiology Reviews. $3,46-65$. 
56. Nagel, G. M., L. J. Bauermeister, C. L. Bratcher, M. Singh, and S. R. McKee. 2013. Salmonella and Campylobacter reduction and quality characteristics of poultry carcasses treated with various antimicrobials in a post-chill immersion tank. Int. J. Food Microbiol. 165:281-286.

57. Niebuhr, S. E., Laury, A., Acuff, G. R., and Dickson, J. S. (2008). Evaluation of Nonpathogenic Surrogate Bacteria as Process Validation Indicators for Salmonella enterica for Selected Antimicrobial Treatments, Cold Storage, and Fermentation in Meat. Journal of Food Protection, 71(4), 714-718. doi:10.4315/0362-028x-71.4.714

58. Northcutt, J. K. and Jones, D. R. (2004). A survey of water use and common industry practices in commercial broiler processing facilities. Journal of Applied Poultry Research.
$12: 435-438$.

59. Northcutt, J. K., J. A. Cason, D. P. Smith, R. J. Buhr, and D. L. Fletchert. 2006. Broiler carcass bacterial counts after immersion chilling using either a low or high volume of water. Poultry Science. 85:594-600.

60. Northcutt, J., Smith, D., Ingram, K. D., Hinton, A., \& Musgrove, M. (2007). Recovery of Bacteria from Broiler Carcasses after Spray Washing with Acidified Electrolyzed Water

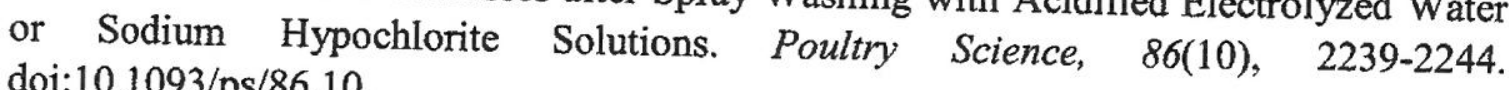
doi: $10.1093 / \mathrm{ps} / 86.10$.

61. Oyarzabal, O.A., 2005. Reduction of Campylobacter spp. by commercial antimicrobials applied during the processing of broiler chickens: a review from the United States
perspective. J. Food Prot. 68:1752-1760.

62. Russell, S. M. (2004/2005, December/January). Salmonella and Campylobacter: A Methods Update. Food Safety Magazine, 1-10.

63. Russel, S. M. (2010). Salmonella reduction calls for multi-hurdle approach. WATT
PoultryUSA, June 2010.

64. Russel, S. M. 2012. Controlling Salmonella in Poultry Production and Processing. CRC Press, Boca Raton, FL.

65. Sanz Perez, B., Lopez Lorenzo, P., Garcia, M. L., Hernandez, P. E. and Ordonez, J. A. (1982) Heat resistance of enterococci. Milchwissenschaft. 37, 724-726.

66. Scallan, E., R. M. Hoekstra, F. J. Angulo, R. V. Tauxe, M. A. Widdowson, S. L. Roy, and P. M. Griffin. 2011. Foodborne illness acquired in the United States-major pathogens.
Emerg. Infect. Dis. 17:7-15.

67. Scharff, R. L. (2011). Economic burden from health losses due to foodborne illness in the United States. Journal of Food Protection, 75(1): 123-131.

68. Scheinberg, J., S. Doores, and C. Cutter 2013. A microbiological comparison of poultry products obtained from farmers' markets and supermarkets in Pennsylvania. J. Food Saf.
$33: 259-264$.

69. Scott, B. R., X. Yang, I. Geornaras, R. J. Delmore, D. R. Woerner, J. O. Reagan, J. B. Morgan, and K. E. Belk. 2015a. Antimicrobial efficacy of a sulfuric acid and sodium sulfate blend, peroxyacetic acid, and cetylpyridinium chloride against Salmonella on

70. Scott, B. R., X. Yang, I. Geornaras, R. J. Delmore, D. R. Woerner, J. M. Adler, and K. E. Belk. 2015b. Antimicrobial efficacy of a lactic acid and citric acid blend against shiga 
toxin-producing Escherichia coli, Salmonella, and nonpathogenic Escherichia coli biotype I on inoculated prerigor beef carcass surface tissue. J. Food Prot. 78:2136-2142.

71. 2. SECTORAL ECONOMIC AND ENERGY PROFILES. (2015, December 11). Retrieved November 29, 2017, from http://www.nrcan.gc.ca/energy/publications/efficiency/industrial/6841

72. Semanchek, J. J., and D. A. Golden. 1998. Influence of growth temperature on inactivation and injury of Escherichia coli 0157:H7 by Heat, Acid, and Freezing. J. Food Prot. 61:395401.

73. Serotypes Profile of Salmonella Isolates from Meat and Poultry Products January 1998 through December 2010. (2013, August 12). Retrieved November 27, 2017, from https://www.fsis.usda.gov/wps/portal/fsis/topics/rulemaking/lut/p/a0/04_Sj9CPykssy0xP LMnMz0vMAfGjzOINAg3MDC2dDbz83RzdDDz9jN3CLPzcDQ28TfÜLsh0VAdZTe2 c!/?1 dmyat=true\&urile=wcm\%3 Apath\%3A\%2Ffsiscontent $\% 2$ Finternet $\% 2$ Fmain $\% 2$ Ftopics $\% 2$ Fdata-collection-andreports\%2Fmicrobiology\%2Fannual-serotyping-reports\%2Fct_index

74. Shen, C., I. Geornaras, K. E. Belk, G. C. Smith, and J. N. Sofos. 2011. Thermal inactivation of acid, cold, heat, starvation, and desiccation stress-adapted Escherichia coli 0157:H7 in moistureenhanced nonintact beef. J. Food Prot. 74:531-538.

75. Shen, C., Y. Luo, X. Nou, Q. Wang, and P. Millner. 2013. Dynamic effects of free chlorine concentration, organic load, and exposure time on the inactivation of Salmonella, Escherichia coli O157:H7 and non-O157 Shiga toxin-producing E. coli. J. Food Prot. 76:386-393

76. Shen, C., P. Norris, O. Williams, S. Hagan, and K. Li. 2016. Generation of chlorine byproducts in simulated wash water. Food Chem. 190: 97-102.

77. Tamblyn, K., \& Conner, D. (1997). Bactericidal activity of organic acids in combination with transdermal compounds against Salmonella typhimurium attached to broiler skin. Food Microbiology, 14(5), 477-484. doi:10.1006/fmic.1997.0112

78. Teotia, J. S. and Miller, B. F. (1975). 'Destruction of Salmonellae on Poultry Meat with Lysozyme, EDTA, X-ray, Microwave and Chlorine' in Poultry Science 54,1388-1394

79. Thomson, J. E., Banwart, G. J., Sanders, D. H., and Mercuri, A. J. (1967). Effect of chlorine, antibiotics, $\beta$-propriolactone, acids, and washing on Salmonella typhimurium on eviscerated fryer chickens. Poultry Science. 46:146-151.

80. Trimble, L. M., W. Q. Alali, K. E. Gibson, S. C. Ricke, P. Crandall, D. Jaroni, and M. Berrang. 2013. Salmonella and Campylobacter prevalence and concentration on pastureraised broilers processed on-farm, in a Mobile Processing Unit, and at small USDAinspected facilities. Food Control. 34:177-182.

81. U.S. Food and Drug Administration, Center for Food Safety and Applied Nutrition. 2001. Analysis and evaluation of preventive control measures for the control and reduction elimination of microbial hazards on fresh and fresh-cut produce. Available at: http://www.fda.gov/Food/FoodScienceResearch/Safe/PracticesforFoodProcesses/ucm090
977.htm.

82. United States Department of Agriculture, Food Safety and Inspection Service. (2003). Use of chlorine to treat poultry chiller water. FSIS Notice 45-03. 
83. United States Department of Agriculture, Food Safety and Inspection Service. (2005). FSIS Directive 7120.1 Amendment 5: Safe and suitable ingredients used in the production of meat and poultry products. Available at: http://www. fsis.usda.gov/OPPDE/rdad/FSISDirectives/7120.1 Amend 5.pfd.

84. United States Department of Agriculture, Food Safety and Inspection Service. (2006). FSIS announces initiative to reduce Salmonella in meat and poultry. Available at: www. fsis.usda.gov/News \& Events/NLR 022306 01/index.asp.

85. United States Department of Agriculture- Food Safety and Inspection Service (USDAFSIS). (2010). New performance standards for Salmonella and Campylobacter in young chicken and turkey slaughter establishments; New Compliance Guides. Fed. Reg. 2728827294.

86. Unites Stated Department of Agriculture-Food Safety and Inspection Service (USDAFSIS). 2013. Strategic Plan: Strategic Performance Working Group Salmonella Action Plan. https://www.fsis.usda.gov/wps/wcm/connect/aae911af-f918-4fe1- bc427b957b2e942a/sap-120413.pdf?mod=ajperes.

87. United States Department of Agriculture-Food Safety and Inspection Service (USDAFSIS). 2017. Safe and Suitable Ingredients Used in the Production of Meat, Poultry, and Egg Products. FSIS Directive 7120.1, Revision 39. : https:// www.fsis.usda.gov/wps/wcm/connect/bab10e09-aefa-483b-8be8809a1 f051d4c/7120.1.pdf?MOD=AJPERES.

88. White, G. C. (1998). Handbook of Chlorination and Alternative Disinfectants. $4^{\text {th }}$ Edition John Wiley and Sons Inc. New York, NY.

89. XLT-4 AGAR. (1996-2016). Retrieved December 1, 2016, from https://catalog.hardydiagnostics.com/cp_prod/Content/hugo/XLT4Agar.htm

90. Yang, Z. P., Y. B. Li, and M. Slavik. 1998. Use of antimicrobial spray applied with an inside-outside bird washer to reduce bacterial contamination on prechilled chicken carcasses. J. Food Prot. 61:829-832. 
Table 1. Mean, standard deviation, and range of microbial populations of aerobic plate count (APC), total coliform (TCC), Escherichia coli, and yeast/molds on broiler carcasses.

\begin{tabular}{|l|l|l|}
\hline & Mean \pm S.D. & Range \\
\hline $\begin{array}{l}\text { Aerobic Plate } \\
\text { Counts (APC) }\end{array}$ & $2.6 \pm 0.3$ & $2.1-3.4$ \\
\hline $\begin{array}{l}\text { Total Coliforms } \\
\text { (TCC) }\end{array}$ & $1.1 \pm 0.6$ & $0.5-2.3$ \\
\hline E. coli (ECC) & $0.7 \pm 0.6$ & $0.5-2.7$ \\
\hline Yeasts and Molds & $2.4 \pm 0.5$ & $1.6-4.0$ \\
\hline
\end{tabular}

Note: Each mean value represents rinsate from 42 broiler carcasses. 
Table 2. Aerobic plate counts (APC) recovered from unstressed or cold-stressed Salmonella cells on both broiler carcasses and wings.

\begin{tabular}{|l|l|l|l|l|}
\hline & \multicolumn{2}{|c|}{ Carcasses } & \multicolumn{2}{c|}{ Wings } \\
\hline Treatment & Unstressed & Cold-Stressed & Unstressed & Cold-Stressed \\
\hline Control & $6.0 \pm 0.1^{\mathrm{Aa}}$ & $6.1 \pm 0.2^{\mathrm{Aa}}$ & $6.2 \pm 0.1^{\mathrm{Aa}}$ & $6.3 \pm 0.2^{\mathrm{Aa}}$ \\
\hline Peroxyacetic acid & $4.3 \pm 0.4^{\mathrm{Ca}}$ & $3.8 \pm 1.0^{\mathrm{Cb}}$ & $4.8 \pm 0.2^{\mathrm{Ca}}$ & $4.6 \pm 0.1^{\mathrm{Db}}$ \\
\hline Lactic acid & $5.1 \pm 0.2^{\mathrm{Ba}}$ & $5.3 \pm 0.1^{\mathrm{Ba}}$ & $5.5 \pm 0.1^{\mathrm{Ba}}$ & $5.2 \pm 0.2^{\mathrm{Cb}}$ \\
\hline Lactic/ citric acid & $5.3 \pm 0.1^{\mathrm{Ba}}$ & $5.3 \pm 0.2^{\mathrm{Ba}}$ & $5.6 \pm 0.1^{\mathrm{Ba}}$ & $5.5 \pm 0.1^{\mathrm{Ba}}$ \\
\hline $\begin{array}{l}\text { Sodium } \\
\text { hypochlorite }\end{array}$ & $5.2 \pm 0.1^{\mathrm{Ba}}$ & $5.3 \pm 0.3^{\mathrm{Ba}}$ & $5.5 \pm 0.1^{\mathrm{Ba}}$ & $5.3 \pm 0.2^{\mathrm{BCb}}$ \\
\hline
\end{tabular}

Note: Each mean value represents rinsate from 6 broilers and 8 wings per treatment.

A,B,C,D Mean values with different capital letters within a column different significantly $(P<0.05)$.

${ }^{\text {a.b }}$ Mean values with different lowercase letters within a row differ significantly $(P<0.05)$. 
Table 3. Unstressed or cold-stressed adapted Salmonella recovered on XLT-4 and HardyCHROM ${ }^{\mathrm{TM}}$ agar from incoluated broiler carcasses.

\begin{tabular}{|l|l|l|l|l|}
\hline & \multicolumn{2}{|c|}{ XLT-4 } & \multicolumn{2}{c|}{ HardyCHROM ${ }^{\mathrm{TM}}$ agar } \\
\hline Treatment & Unstressed & Cold-Stressed & Unstressed & Cold-Stressed \\
\hline Control & $5.6 \pm 0.2^{\mathrm{Aa}}$ & $5.4 \pm 0.4^{\mathrm{Aa}}$ & $5.6 \pm 0.2^{\mathrm{Aa}}$ & $5.6 \pm 0.2^{\mathrm{Aa}}$ \\
\hline Peroxyactic acid & $3.9 \pm 0.4^{\mathrm{Da}}$ & $3.3 \pm 0.7^{\mathrm{Db}}$ & $4.1 \pm 0.3^{\mathrm{Da}}$ & $3.8 \pm 0.9^{\mathrm{Ca}}$ \\
\hline Lactic acid & $4.3 \pm 0.4^{\mathrm{Ca}}$ & $3.7 \pm 0.2^{\mathrm{Cb}}$ & $4.5 \pm 0.2^{\mathrm{Ca}}$ & $3.96 \pm 0.3^{\mathrm{Cb}}$ \\
\hline Lactic/Citric acid & $4.5 \pm 0.3^{\mathrm{BCa}}$ & $4.2 \pm 0.6^{\mathrm{Bb}}$ & $4.9 \pm 0.2^{\mathrm{Ba}}$ & $4.5 \pm 0.6^{\mathrm{Bb}}$ \\
\hline $\begin{array}{l}\text { Sodium } \\
\text { hypochlorite }\end{array}$ & $4.7 \pm 0.3^{\mathrm{Ba}}$ & $4.1 \pm 0.3^{\mathrm{Bb}}$ & $5.0 \pm 0.1^{\mathrm{Ba}}$ & $4.2 \pm 0.6^{\mathrm{BCb}}$ \\
\hline
\end{tabular}

Note: Each mean value represents rinsate from 6 broilers.

A,B,C,D Mean values with different capital letters within a column different significantly $(P<0.05)$.

${ }^{a, b}$ Mean values with different lowercase letters within a row differ significantly $(P<0.05)$. 
Table 4. Unstressed or cold-stressed adapted Salmonella recovered on XLT-4 and HardyCHROM ${ }^{\mathrm{TM}}$ agar from inoculated broiler wings.

\begin{tabular}{|l|l|l|l|l|}
\hline & \multicolumn{2}{|c|}{ XLT-4 } & \multicolumn{2}{c|}{ HardyCHROM $^{\mathrm{TM}}$} \\
\hline Treatment & Unstressed & Cold-Stressed & Unstressed & Cold-Stressed \\
\hline Control & $6.0 \pm 0.1^{\mathrm{Aa}}$ & $5.9 \pm 0.1^{\mathrm{Aa}}$ & $5.8 \pm 0.4^{\mathrm{Aa}}$ & $5.9 \pm 0.1^{\mathrm{Aa}}$ \\
\hline Peroxyacetic acid & $4.4 \pm 0.2^{\mathrm{Da}}$ & $4.2 \pm 0.3^{\mathrm{Cb}}$ & $4.6 \pm 0.3^{\mathrm{Da}}$ & $4.4^{\mathrm{Da}} 0.9^{\mathrm{Da}}$ \\
\hline Lactic acid & $4.7 \pm 0.1^{\mathrm{Da}}$ & $4.2 \pm 0.3^{\mathrm{Cb}}$ & $5.0 \pm 0.2^{\mathrm{Ca}}$ & $4.5 \pm 0.3^{\mathrm{Cb}}$ \\
\hline Lactic/Citric acid & $5.0 \pm 0.1^{\mathrm{Ca}}$ & $4.6 \pm 0.4^{\mathrm{Bb}}$ & $5.3 \pm 0.1^{\mathrm{Ba}}$ & $5.0 \pm 0.2^{\mathrm{Bb}}$ \\
\hline $\begin{array}{l}\text { Sodium } \\
\text { Hypochlorite }\end{array}$ & $5.2 \pm 0.1^{\mathrm{Ba}}$ & $4.8 \pm 0.1^{\mathrm{Bb}}$ & $5.3 \pm 0.1^{\mathrm{Ba}}$ & $5.0 \pm 0.2^{\mathrm{Bb}}$ \\
\hline
\end{tabular}

Note: Each mean value represents rinsate from 8 wings per treatment.

A,B.C,D Mean values with different capital letters within a column different significantly $(P<0.05)$.

a.b Mean values with different lowercase letters within a row differ significantly $(P<0.05)$. 
Table 5. Unstressed or cold-stressed adapted Enterococcus faecium recovered from inoculated both broiler carcasses and wings.

\begin{tabular}{|l|l|l|l|l|}
\hline & \multicolumn{2}{|c|}{ Carcasses } & \multicolumn{2}{c|}{ Wings } \\
\hline Treatment & Unstressed & Cold-Stressed & Unstressed & Cold-Stressed \\
\hline Control & $5.4 \pm 0.2^{\mathrm{Aa}}$ & $6.1 \pm 0.1^{\mathrm{Ab}}$ & $6.3 \pm 0.1^{\mathrm{Aa}}$ & $6.1 \pm 0.2^{\mathrm{Aa}}$ \\
\hline Peroxyacetic acid & $3.7 \pm 0.4^{\mathrm{Db}}$ & $4.0 \pm 0.4^{\mathrm{Da}}$ & $4.3 \pm 0.3^{\mathrm{Da}}$ & $4.2 \pm 0.2^{\mathrm{Da}}$ \\
\hline Lactic acid & $4.8 \pm 0.2^{\mathrm{Ca}}$ & $4.6 \pm 0.3^{\mathrm{Ca}}$ & $5.3 \pm 0.1^{\mathrm{Ca}}$ & $5.0 \pm 0.3^{\mathrm{Cb}}$ \\
\hline Lactic/Citric acid & $5.2 \pm 0.2^{\mathrm{ABa}}$ & $5.0 \pm 0.3^{\mathrm{Ba}}$ & $5.2 \pm 0.1^{\mathrm{Ca}}$ & $5.2 \pm 0.2^{\mathrm{Ba}}$ \\
\hline $\begin{array}{l}\text { Sodium } \\
\text { hypochlorite }\end{array}$ & $5.0 \pm 0.1^{\mathrm{BCa}}$ & $5.1 \pm 0.2^{\mathrm{Ba}}$ & $5.0 \pm 0.2^{\mathrm{Ba}}$ & $5.0 \pm 0.2^{\mathrm{Ca}}$ \\
\hline
\end{tabular}

Note: Each mean value represents rinsate from 6 broilers and 8 wings per treatment.

A.B.C.D Mean values with different capital letters within a column different significantly $(P<0.05)$.

a.b Mean values with different lowercase letters within a row differ significantly $(P<0.05)$. 
Table 6. Comparing reduction of unstressed or cold-stress adapted Salmonella and Enterococcus faecium recovered from inoculated broiler carcasses.

\begin{tabular}{|l|l|l|l|l|l|l|}
\hline & \multicolumn{3}{|c|}{ Unstressed } & \multicolumn{3}{c|}{ Cold-Stressed } \\
\hline Treatment & XLT-4 & HardyCHROM & $\begin{array}{l}\text { Bile } \\
\text { Esculin }\end{array}$ & XLT-4 & HardyCHROM & Bile Esculin \\
\hline Peroxyacetic acid & $1.7 \pm 0.4^{\mathrm{A}}$ & $1.5 \pm 0.3^{\mathrm{A}}$ & $1.7 \pm 0.4^{\mathrm{A}}$ & $2.1 \pm 0.7^{\mathrm{A}}$ & $1.8 \pm 0.9^{\mathrm{A}}$ & $2.0 \pm 0.4^{\mathrm{A}}$ \\
\hline Lactic acid & $1.3 \pm 0.4^{\mathrm{A}}$ & $1.1 \pm 0.2^{\mathrm{A}}$ & $0.5 \pm 0.2^{\mathrm{B}}$ & $1.7 \pm 0.2^{\mathrm{A}}$ & $1.7 \pm 0.3^{\mathrm{A}}$ & $1.4 \pm 0.3^{\mathrm{A}}$ \\
\hline Lactic/Citric acid & $1.1 \pm 0.3^{\mathrm{A}}$ & $0.7 \pm 0.2^{\mathrm{B}}$ & $0.2 \pm 0.2^{\mathrm{C}}$ & $1.2 \pm 0.5^{\mathrm{A}}$ & $1.4 \pm 0.5^{\mathrm{A}}$ & $1.1 \pm 0.3^{\mathrm{A}}$ \\
\hline $\begin{array}{l}\text { Sodium } \\
\text { hypochlorite }\end{array}$ & $0.9 \pm 0.3^{\mathrm{A}}$ & $0.6 \pm 0.1^{\mathrm{B}}$ & $0.4 \pm 0.1^{\mathrm{B}}$ & $1.3 \pm 0.3^{\mathrm{B}}$ & $1.7 \pm 0.6^{\mathrm{A}}$ & $1.0 \pm 0.2^{\mathrm{B}}$ \\
\hline
\end{tabular}

Note: Each mean value represents rinsate from 6 broilers carcasses per treatment.

$A, B, C, D$ Mean values with different capital letters within a within a row under unstressed or coldstressed column different significantly $(P<0.05)$. 

Table 7. Comparing reduction of unstressed or cold-stress adapted Salmonella and Enterococcus
faecium recovered from inoculated broiler wings

\begin{tabular}{|l|l|l|l|l|l|l|}
\hline & \multicolumn{3}{|c|}{ Unstressed } & \multicolumn{3}{c|}{ Cold-Stressed } \\
\hline Treatment & XLT-4 & $\begin{array}{l}\text { HardyCHRO } \\
\text { M }\end{array}$ & Bile Esculin & XLT-4 & HardyCHROM & Bile Esculin \\
\hline Peroxyacetic acid & $1.3 \pm 0.2^{\mathrm{B}}$ & $1.1 \pm 0.2^{\mathrm{B}}$ & $2.0 \pm 0.3^{\mathrm{A}}$ & $1.7 \pm 0.3^{\mathrm{A}}$ & $1.3 \pm 0.3^{\mathrm{B}}$ & $1.9 \pm 0.2^{\mathrm{A}}$ \\
\hline Lactic acid & $1.3 \pm 0.1^{\mathrm{A}}$ & $0.8 \pm 0.1^{\mathrm{B}}$ & $1.0 \pm 0.1^{\mathrm{A}}$ & $1.7 \pm 0.3^{\mathrm{A}}$ & $1.5 \pm 0.5^{\mathrm{B}}$ & $1.2 \pm 0.3^{\mathrm{B}}$ \\
\hline Lactic/Citric acid & $1.0 \pm 0.1^{\mathrm{A}}$ & $0.4 \pm 0.1^{\mathrm{B}}$ & $1.0 \pm 0.1^{\mathrm{A}}$ & $1.2 \pm 0.4^{\mathrm{A}}$ & $0.9 \pm 0.2^{\mathrm{A}}$ & $1.0 \pm 0.2^{\mathrm{A}}$ \\
\hline $\begin{array}{l}\text { Sodium } \\
\text { hypochlorite }\end{array}$ & $0.9 \pm 0.1^{\mathrm{B}}$ & $0.5 \pm 0.1^{\mathrm{C}}$ & $1.3 \pm 0.2^{\mathrm{A}}$ & $1.1 \pm 0.1^{\mathrm{A}}$ & $0.9 \pm 0.2^{\mathrm{A}}$ & $1.1 \pm 0.2^{\mathrm{A}}$ \\
\hline
\end{tabular}

Note: Each mean value represents rinsate from 8 wings per treatment.

$A, B, C, D$ Mean values with different capital letters within a row under unstressed or cold-stressed column different significantly $(P<0.05)$. 